\title{
WILEY
}

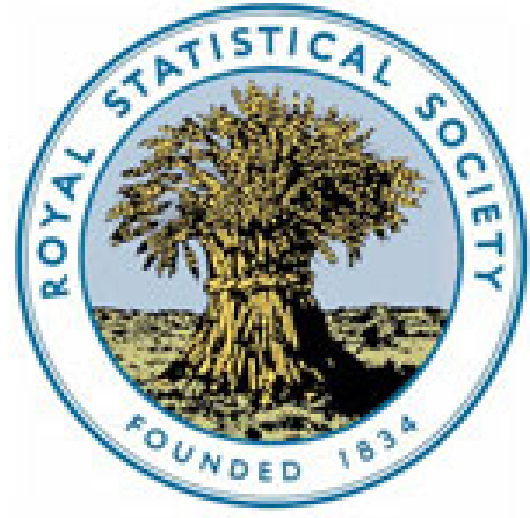

Some Canadian Railway and Commercial Statistics

Author(s): Joseph G. Colmer

Source: Journal of the Royal Statistical Society, Vol. 51, No. 1 (Mar., 1888), pp. 74-112

Published by: Wiley for the Royal Statistical Society

Stable URL: http://www.jstor.org/stable/2979083

Accessed: 24/06/2014 20:15

Your use of the JSTOR archive indicates your acceptance of the Terms \& Conditions of Use, available at http://www.jstor.org/page/info/about/policies/terms.jsp

JSTOR is a not-for-profit service that helps scholars, researchers, and students discover, use, and build upon a wide range of content in a trusted digital archive. We use information technology and tools to increase productivity and facilitate new forms of scholarship. For more information about JSTOR, please contact support@ jstor.org.

Wiley and Royal Statistical Society are collaborating with JSTOR to digitize, preserve and extend access to Journal of the Royal Statistical Society. 


\section{Some Canadian Railway and Commercial Statistics.}

\section{By Joseph G. Colmer, Esq.}

[Read before the Royal Statistical Society, 21st February, 1888.

FRederick Hendriks, Esq., F.I.A., a Vice-President, in the Chair.]

So many papers have been read during the past few years with reference to the Dominion of Canada, and so little ground has been left uncovered, that I must own to feeling some diffculty in choosing a subject, when bonoured with an invitation to read a paper before this Society. However, after consideration, I have decided to place before you some observations on the development of railways and the growth of trade and commerce in Canada since the Confederation of the various provinces, and on some of the results expected to follow the completion of the Canadian Pacific Railway, a work which has justly attracted attention in most parts of the world.

It is necessary to point out in the first place, that the rapid extension of railways in Canada (see Appendix A) has been mainly owing to the manner in which such enterprises have been assisted by the Dominion and Provincial Governments and by municipalities. This encouragement has assumed a much more tangible form than mere benevolent approval, for it has taken the shape of large subsidies of money, and in many cases, jn recent years, of extensive grants of fertile land. There is a special department of the Dominion Government to deal with matters relating to the railways and canals of the country, with a cabinet minister at its head; and it may be stated in passing that out of an amount of about 135 million $£$ sterling expended on railways, the Canadian people bave in one way and anotber contributed 32 million $£$. The result of this policy is that new districts have been opened ap, and older settlements developed, with a rapidity which would probably have been impossible in any other circumstances. In most of the colonies the railways belong to and are worked by the Governments, but this principle does not obtain in Canada, with the two exceptions of the Intercolonial and Prince Edward Island Railways, which were entirely consurucied with public money. The otber lines are in the hands of companies, which have raised and spent the money required for construction and other purposes, and any subsidies of money or of land given by Governments or municipalities have as a rule been handed over absolutely, and, excepting in the case of land, forms an annual 
charge upon the people. The land soon becomes of considerable value to the railway companies, as its price is naturally largely increased by the opening up of means of communication, and immediatiely represents a valuable asset. In addition, its settlement causes money to flow into the railway exchequer in the shape of earnings for the carriage of increased traffic. The policy which has governed railway construction in Canada is very different to that prevailing in England. In the former, lines have frequently been made into the wilderness, as the advance guards of civilisation, opening up fertile lands for the use of man which would otherwise have remained inaccessible. They bave not always returned dividends immediately, but the capital has generally been issued at a discount, and taken up with a full knowledge $o i$ the circumstances, and in the hope of future increment in value. Great Britain, on the other hand, has had to deal with a limited extent of country and a greater density of population-advantages from a railway, if not from a national point of view, and favourable for the raising of capital without the aid of the State.

Railway construction in Canada did not proceed at a very rapid raie prior to 1867 . The first railway opened was in 1837 , and to the province of Quebec belongs this honour. It ran from La Prairie-a small town 7 miles from Montreal-to St. Johns, a distance of 16 miles. The line was first worked by horses, and then by steam, but its use was discontinued some years after, and the rails removed on the construction of the Champlain Railway, now a portion of the Grand Trunk system. No further railways were built till 1845 , and even in 1850 only 71 miles were in operation. In the latter year, however, considerable activity appears to have been awakened, several new and important undertakings were commenced, notably the Grand Trunk, Great Western, and Northern Railways, and in 1860 some 2,087 miles had been completed. This was increased to 2,380 in 1867 , and in Appendix $\mathrm{B}$ will be found a statement giving the names of the lines then in operation, and the cost of their construction. Railway statistics for that period are not easily obtainable, but it is interesting to know that in 1866 the earnings of 2,150 miles of line were $11 \frac{1}{2}$ million of dollars, and the expenses $6 \frac{1}{2}$ millions, leaving a surplus of 5 millions, sufficient to pay nearly five per cent. upon the capital contributed by the public. About this time several new companies were incorporaced, and the mileage increased gradually until in 1874 it is recorded as 2,642 . In 1875 it had advanced to 4,826, owing to the completion of works in progress on the Great Western, Intercolonial, Prince Edward Island, and other railways. The rupid increase 
continued, until in 1886 there were ro,697 miles in operation, while I I,523 miles were actually completed, and a further 751 miles under construction (see table in Appendix). Of this mileage the Government have constructed and work 1,190 miles. Included in the figures are of course the 4,3 I 9 miles owned and controlled by the Canadian Pacific Railway Company, whose line from ocean to ocean was completed in 1885 . To summarise, the miles of railway in operation increased from 2,258 in 1867 to 10,697 in 1886 . In the same period the population advanced from $3,400,000$ to nearly $5,000,000$, the annual revenue from $\$ 13,687,928$ to $\$ 33,177,040$, and the annual trade-not including the inter-provincial trade-from $\$ \$_{1} 3_{1}, 027,532$ to $\$ 189,675,875$. This forms a very satisfactory and striking record of the progress made in recent years, and considering the immense area of country still to be opened up for settlement, and the varied nature of its resources, it is certain beyond a doubt that great development will be apparent in the future. Canada now comes after Great Britain and India (even if not entitled to precede India) in the British Empire in the extent of railways, and in the 1885 returns of the railways of the world she held the eighth place on the list, a position most credituble to a community containing but 5 millions of people. As the result it is now possible to travel from any Canadian Atlantic port to the Pacific ocean entirely through British territory, and there are no places on the way of any importance which do not possess the advantages of railway communication.

It is the custom of many persons to shrug their shoulders eloquently when mention is made of railways in Canada as an investment. I wish to claim your attention for a few minutes on this matter, as it is one of great importance. I will take as the basis of my remarks the list of railways, in whose bonds and stocks transactions take place in London, quoted each week in the "Canadian Gazette." The nominal capital included in this statement amounts to about 104 million $£$ sterling. An analysis shows that $34,48 \mathrm{I}, 908 \mathrm{l}$. of this (including over 8 million $£$ of Grand Trunk capital) is quoted at par and above, and regularly pays dividends varying from 4 per cent. upwards. Then there is $58,017,461 l$. quoted under par, of which however 18,969,995l. (including about 2 million $£$ of Grand Trunk capital) regularly pays dividends; of the balance of $39,047,466 l$., 38 ,091,466l. represents Grand Trunk Railway capital, 17,933,791l. of which has paid dividends frequently, while on the remainder, that is the ordinary stock, no dividends have ever been paid. The remaining $11 \frac{1}{2} \mathrm{mil}$ lions is not quoted on the market, but it is not by any means worthless. Seven and a half millions of the stock is not known on the London market, is held by contractors or other companies, 
or at any rate is not in the possession of the public. I have the authority of the editor of the "Stock Exchange Year Book" for this statement. Of the remaining 4 millions more than 3 millions is dividend paying, and is not quoted because there is no demand for it. Deducting the Grand Trunk capital not earning dividend in 1886, and the stock mentioned as not known here, the amount invested in Canadian railways is reduced to about $58 \frac{1}{2}$ million $£$, over $56 \frac{1}{2}$ millions of which is dividend earning, and cannot be purchased below its par value except in a very few cases.

It is right I should explain that my calculations of the dividends earned by Canadian railways were taken from financial publications issued early in 1887, which of course dealt with the first half of the previous year only. Since however my paper has been printed, the 1888 editions of the works referred to have been published, and they strengthen my case considerably. For I find that the 4 per cent. guaranteed stock of the Grand Trunk Railway, amounting to 5,2 19,194l., paid dividerds in May and October last year, and also the arrears of the first six months of 1886 . In addition, the first preference stock, 3,2 18,149l., paid 2 per cent. in October last. Then again for the half year ended 31st December last, dividends are to be paid on the 4 per cent. guaranteed stock $(5,219,794 l$.). The full dividend of 5 per cent. is also to be paid on the first preference stock $(3,218,149 l$. $)$ for the whole year, and a dividend at the rate of 13 s. $4 d$. per annum on the second preference stock $(2,327,795 l$.$) . Therefore this leaves about 7,168,055l. of Grand$ Trunk third preference stock (which has paid dividends in the last few years, though not recently), and the ordinary stock as not at present earning any dividend. To the extent by which the amount of Grand Trank capital not earning dividend is reduced, so is the proportion of capital invested in the Canadian railways which is dividend-earning increased, and by so much is my contention strengthened, that the general unfavourable reputation which has been given to Canadian railways as investments is not deserved.

As to the Grand Trunk Railway, let me say that it has been an immense boon to the country, and an important factor in its development. It is a matter for regret not only to the shareholders, but in many other ways, that its success as a financial enterprise has, owing to exceptional circumstances, been somewhat delayed, but for this Canada is not to blame. Indeed the country has suffered from it, as it is indirectly responsible for the diversion of a good deal of capital and labour which might otherwise have been used to open up its varied resources. The future of the district served by the railway has no doubt been somewhat discounted, but I look upon that future hopefully, and there are many who believe, both in Canada and in Great Britain, that there 
is an era of prosperity before the company. It owns and controls about 2,600 miles of line in the Dominion, and besides has most valuable connections with the United States' railway system; the country through which it runs is very fertile and by no means so well populated as it is bound to be at no very distant date; and the general development of agriculture, manufactures, and trade and commerce which is taking place must beneficially affect all railways. There can be no doubt whatever that in the future as in the past, the Grand Trunk Railway is bound to be inseparably associated with the progress of the Dominion, and to share in connection with other Canadian railways the prosperity that is believed to be before the country.

A few words as to the railways worked by the Government will no doubt be interesting. The main line oi the Intercolonial Railway runs from Halifax to Quebec, a distance of 688 miles, and forms a part of the through mail line from the Atlantic to the Pacific Ocean. The construction of the railway was one of the conditions upon which the maritime provinces joined the Confederation, and it was also desired for military purposes by the Imperial Government, who guaranteed the interest on a loan not exceeding 15 million $\$$ towards its cost. It is largely owing to official representations that, for military reasons, the line takes an apparently circuitous route. The total mileage, including branches, is 886 miles, and the amount expended upon the railway up to the 30 th June, 1886, was about 9 million $£$ sterling. It is hardly necessary to say that the guarantee referred to was purely a formal matter, as Canada has regularly paid the interest upon the money borrowed for the purpose, and the Imperial Government has never therefore been required to contribute a penny towards the expenditure. The following figures will give an idea of the progress made by the railway in recent years :-

\begin{tabular}{|c|c|c|}
\hline & 1880. & 1886. \\
\hline 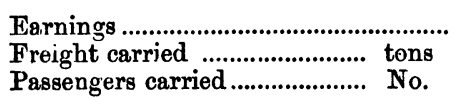 & $\begin{array}{r}\$ 1,506,298 \\
56 \mathrm{I}, 294 \\
58 \mathrm{I}, 483\end{array}$ & $\begin{array}{r}\$ 2,383,201 \\
1,008.545 \\
889,864\end{array}$ \\
\hline
\end{tabular}

The expenses however have more than kept pace with the increase in the earnings, and there is usually a small deficit, which has to be made up out of the Canadian revenue. Sometimes it is very small, and in 1886 it was about 20,000 . This is largely owing to the route taken by the railway, and to the fact that low rates are charged by the Government primarily to encourage trade and commerce, and to develop the country through which it passes. It has been an important factor in the 
commercia! and political development of the maritime provinces, and indeed of the whole of Canada, for without it confederation would have been more or less impossible, and the Dominion would have been barred from access to the Atlantic Ocean in the winter excepting through the United States.

The Windsor branch, which runs from Halifax to Windsor ( 32 miles), is maintained by the Government, but worked by the Windsor and Annapolis Railway Company. The Government's share of the earnings is generally sufficient to cover the expenses of maintenance. In 1886 there was a profit shown of $\$ 4,429$.

What is known as the Eastern Extension Railway extends from New Glasgow to Port Mulgrave on the Straits of Canso, and connects with Cape Breton by means of a ferry. It is 80 miles long, and was purchased from the Nova Scotian Government in 1884 by the Dominion Government for $\$ \mathbf{1}, 200,000$. The total capital expenditure to June, 1886, was $\$ 1,284,496$. In 1885-86 the earnings were $\$ 66,893$, and the expenses $\$ 94,756$. The repairs and renewals were exceptionally heavy, and there was a decrease in the earnings due to a falling off in the fish traffic.

The Prince Edward Island Railway, with a mileage of 2 I $1 \frac{1}{2}$ miles, was opened for traffic in April, 1875. It was built as a condition of the Island joining the Confederation. Its cost up to the 30th June, 1886, was $\$ 3,735,98 \mathrm{r}$. The traffic of the road is comparatively light, and it is likely to be some time before the receipts cover the expenditure. In 1885-86 the earnings were $\$ 155,584$, and the expenses $\$ 216,744$.

As a net result the Government railways in 1885-86 were worked at a loss of $\$ 190,637$, which was larger by $\$ 65,170$ than in the preceding year, but it is stated in the Official Statistical Absiract in explanation, that on the Intercolonial Railway \$ I I 5, 000 were spent for improvements generally charged to capital, and that the repairs necessary on the Eastern Extension Railway were unusually beavy.

Taking the financial position of the Canadian railways however as a whole, the result is very satisfactory. The total capital from all sources so invested is $\$ 653,376,144$, but from this must be deducted Government and municipal aid amounting in all to $\$ 156,904,449$, leaving a bạlance of $\$ 496,471,704$ as representing the capital subscribed by the public. For this sum, which is about equal to the capital of the London and North Western Railway Company with its I,800 miles of line, Canada has a mileage of close upon 12,000. I append a statement showing the traffic and working expenses for the last ten years, for the last few years of which it must be remembered that Canada has felt, to a certain extent, that wave of depression which has been passing over the world. 


\begin{tabular}{|c|c|c|c|c|c|}
\hline Year. & Miles. & $\begin{array}{l}\text { Number } \\
\text { of Passengers } \\
\text { Carried. }\end{array}$ & $\begin{array}{c}\text { Tons of } \\
\text { Freight Carried. }\end{array}$ & $\begin{array}{l}\text { Earnings, in } \\
\text { Doilurs. }\end{array}$ & $\begin{array}{l}\text { Working } \\
\text { Expenses, in } \\
\text { Dollars. }\end{array}$ \\
\hline 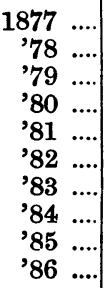 & $\begin{array}{r}5,574 \\
6,143 \\
6,484 \\
6,891 \\
7,260 \\
7,530 \\
8,726 \\
9,658 \\
10,149 \\
10,697\end{array}$ & $\begin{array}{l}6,073,233 \\
6,443,924 \\
6,523,816 \\
6,462,948 \\
6,943,671 \\
9,352,325 \\
9,579,948 \\
9,981,358 \\
9,672,599 \\
9,861,024\end{array}$ & $\begin{array}{r}6,859,796 \\
7,883,472 \\
8,348,810 \\
9,938,858 \\
12,065,323 \\
13,575,787 \\
13,266,255 \\
13,712,269 \\
14,659,271 \\
15,670,460\end{array}$ & $\begin{array}{l}18,742,053 \\
20,520,078 \\
19,925,066 \\
23,561,447 \\
27,985,509 \\
29,027,789 \\
33,244,586 \\
33,481,705 \\
32,227,469 \\
33,389,382\end{array}$ & $\begin{array}{l}15,290,091 \\
16,100,102 \\
16,188,282 \\
16,840,705 \\
20,121,418 \\
22,390,709 \\
24,691,667 \\
25,595,342 \\
24,015,351 \\
24,177,582\end{array}$ \\
\hline
\end{tabular}

It must be borne in mind that many hundreds of miles of the railways constructed since 1880 run through districts very thinly inhabited at present, and bave not yet made any appreciable effect upon the above returns. The passenger traffic has however increased by more than 50 per cent. since 1877, freight traffic by 130 per cent., earnings by 83 per cent., while the working expenses are only 60 per cent higher than they were. The proportion of working expenses to receipts in 1877 was 8I per cent., in 1886 it was 72 per cent. Things therefore seem to be moving in the right direction. I can remember the time when some of our great English lines were not as prosperous as they are now, and I think that an examination of the Board of Trade returns would reveal the fact that there is still a very large amount of capital locked up in British railways which does not yield any return. But as I have shown the financial position of Canadian railways is on the whole very satisfactory, and the country is only on the threshold of the progress that is before it. Canada has 12,000 miles of railways, representing a capital of about 8,500l. per mile. The Atlantic and Pacific provinces are now connected, and with an outlet on the Pacific as well as on the Atlantic, the opportunities and facilities for development are greater than at any previous time. These new facilities have not yet been availed of to any great extent, but it will be generally admitted that in consequence of their existence and the rapid increase in trade and commerce which is expected to follow, the railway outlook; in connection with future traffic, earnings, and profits, is very hopeful. The national credit of Canada has much advanced in the last twenty years, even in the last ten years (not long ago 5 per cent. had to be paid for Government loans, while two years ago money was borrowed at $3 \frac{1}{2}$ per cent., and this stock issued at $9 \mathrm{I}$ has now risen to $\mathrm{IO}_{4}$ ), and the credit of the railways has also improved in sympathy, although not to so large an extent, but progress and development, which benefits the community as 
a whole, must also operate favourably upon railway receipts. As to the general effect of the railway enterprise to which I have been referring, it is sufficient to say that without it Canada could not possibly have prospered as she has done, although as already stated the country cannot yet be said to have felt anything like the full influence of the construction of the great works which the last few years have witnessed.

Manitoba and the North-West, and British Columbia, ten years ago had no railway communication, and it is only as yesterday that this necessity of modern times was extended to them. On the other hand, the western portions of the United States have been traversed by railways for forty years, and the result is that their population is numbered by millions, while owing to the inaccessibility of the Canadian prairies until recently, their inhabitants are still computed by thousands. As a rule it is only possible to get accurate statistics of the progress of Canada in the census years. A special census of Manitoba was however taken in 1886, which gives a record of the progress made since 1881. As the province only received railway communication in 1878, and as there were no extensions of importance until after 1881, a comparison of the figures enables a very good idea to be formed of the development which has taken place. The following figures will be interesting on this point:-

\begin{tabular}{|c|c|c|}
\hline & 1881. & 1886. \\
\hline 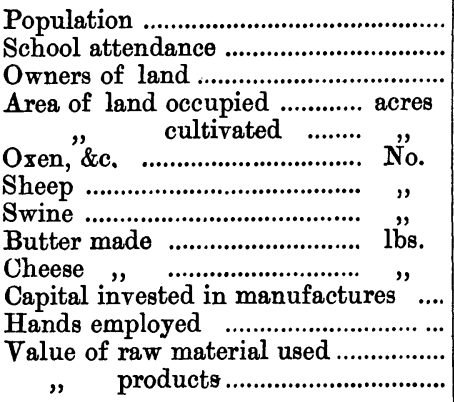 & $\begin{array}{r}62,260 \\
6,979 \\
8,742 \\
2,384,337 \\
250,416 \\
60,000 \\
6,000 \\
17,282 \\
1,000,000 \\
19,681 \\
£ 276,666 \\
344 \\
£ 384,964 \\
£ 682,605\end{array}$ & $\begin{array}{r}108,640 \\
17,579 \\
16,351 \\
4,171,224 \\
752,571 \\
144,600 \\
16,000 \\
101,490 \\
3,500,000 \\
74,825 \\
£ 682,226 \\
545 \\
£ 562,967 \\
£ 1,079,893\end{array}$ \\
\hline
\end{tabular}

These figures are all the more remarkable owing to the fact that a considerable depression and stagnation took place for a time after the inflated speculation which raged in Winnipeg in 1881-82.

But for the energy which has been displayed, these provinces must have remained isolated not only from each other and from the eastern provinces, but from Great Britain ; the development of the Dominion would have been retarded; emigrants would have been obliged as they were in the past to settle under another flag;

VOL. II. PART I. 
the new markets for British products, and the new source of food supplies to Great Britain, which the western provinces are likely to prove as they become filled up with people, would have remained closed ; and the alternative route to the East, the "Queen's High"way," as it has been appropriately called, would not have become an accomplished fact. It cannot be too strongly emphasised that the Canadians have done much in a national sense towards building up the railway system by their contributions in aid of the various lines, and in the building of such railways as the Intercolonial and Canadian Pacific. Without them the country would in all probability have remained scattered and divided, as was the case before Confederation, instead of being politically and commercially united as at present.

Since confederation commerce has also progressed very rapidly, and in order to illustrate this in a general way I have prepared a statement (Appendix C) showing the total aggregate of the inports and exports from 1868 to 1886 . This return, although satisfactory in itself, does not by any means give an adequate and comprehensive idea of the commercial progress of Canada in recent years. It merely shows the outside trade of the Dominion, and does not take into account either the immense strides made by the country in developing its resources, and the consequent increase of the inter-provincial trade, rendered possible by the construction of connecting railways, or the increase that is apparent in the wealth of the inhabitants. The increase of the trade from $\$ 131,027,53^{2}$ to $\$ 189,675,875$ in the period mentioned indicates progress, but a glance down the list shows how the figures have varied. In 1873 they were as high as $\$ 2$ I $7,801,203$, in 1879 as low as $\$ 153,455,682$, and in 1882 reached the total of $\$ 230,339,826$. Canadian trade moves in cycles as in other countries, and I have therefore divided the nineteen years into four periods, the first of four and the rest of five years, in order to arrive at a comparative yearly average for the following periods:-

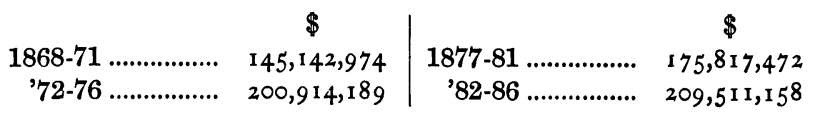

It is only fair to say that in the third period Canada was suffering from extreme depression. Besides the country has, it is truly said, been undergoing a transition within the last nine years. Although agriculture is the premier industry, and must remain so for a long time, owing to the immense areas of fertile land awaiting cultivation, it is apparent even to the superficial observer that the manufacturing industries are developing in a very marked manner. 
The imports for 1885 are below divided into classes, to give an idea of the nature of the trade. Similar figures are given for the year 1875, for purposes of comparison :-

Imports by Classes (Home Consumption).

\begin{tabular}{|c|c|c|}
\hline & 1875. & 1885. \\
\hline $\begin{array}{ll}\text { Manufactures of } & \text { iron and steel } \\
\text { metals other than iron } & \\
\text { silk } & \text { cottons }\end{array}$ & $\begin{array}{c}\$ \\
19,095,716 \\
1,491,384 \\
2,219,160 \\
9,830,836 \\
12,767,575 \\
21,339,991 \\
29,042,973 \\
10,652,870 \\
2,210,085 \\
10,968,067\end{array}$ & $\begin{array}{r}\$ \\
11,657,189 \\
2,309,771 \\
2,305,168 \\
6,241,283 \\
9,053,626 \\
17,258,514 \\
18,089,941 \\
20,035,767 \\
2,954,244 \\
12,571,009\end{array}$ \\
\hline
\end{tabular}

It will be seen that the imports of all kinds of manufactures have decreased, but it is equally a fact that the corresponding industries of the Dominion have increased in a still larger ratio. In support of this statement the importation of raw materials may be quoted. The cotton imported from 1874 to 1878, five years, aggregated 25,64r,000 lbs. From 1881 to 1885 it had increased to $104,528,000$ lbs., or more than quadruple that of the first period. In the same time the importation of wool increased by $15,439,124$ lbs., and the exports decreased $6,627,563 \mathrm{lbs}$., or a difference comparing the two periods of $22,066,783$ lbs. available for manufacturing. The importation of pig iron has more than doubled also. It is difficult to get reliable statistics relating to the manufacturing industries, excepting at the time the census is taken every decade, but the following figures serve to show the rapid advance that was made between 1871 and 1881 :-

\begin{tabular}{|c|c|c|}
\hline & 1871. & 1881. \\
\hline 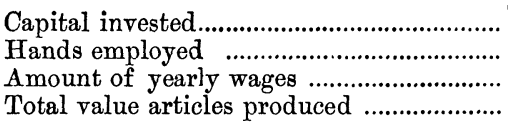 & $\begin{array}{r}\$ 77,694,020 \\
187,942 \\
\$ 40,851,069 \\
\$ 221,617,773\end{array}$ & $\begin{array}{r}\$ 165,302,623 \\
254,935 \\
\$ 59,429,0 \cap 2 \\
\$ 309,676,068\end{array}$ \\
\hline
\end{tabular}

A list of the principal industries established in Canada at the last census of 1881, with the amount of capital so invested, and the estimated yearly product, is given in Appendix D. It has been stated by successive Ministers of Finance, in making their annual statements, that the industrial development has been more marked since 1881 than in any previous period in the industrial history of 
Canada. A partial investigation made in 1884 and 1885 indicated that in the older provinces there had been in 1884 over 1878 an estimated increase of 75 per cent. in the number of hands employed, in the amount of wages paid, and in the capital invested, while in the value of goods produced the increase had been 93 per cent. As also bearing upon this point I may say that in 1871 there were twenty cities and towns of 5,000 inhabitants and over with a total population of $43^{\circ}, 043$, and that in 1881 the number had advanced to 37 , with a total population of $660,0_{4} \circ$, an increase of 85 per cent. and 53 per cent. respectively. The smaller towns and villages would probably show a greater comparative increase were statistics available, and I believe that the next census in 1891 will indicate a remarkable advance both in the growth of the urban and rural population. Those who saw the machinery, general hardware, wooden ware, silks, cottons, woollens, leather goods, stationery, books, boots and shoes, pianos, and articles of food and domestic use in the Canadian court at the Colonial and Indian Exhibition in 1886, will be able to form some opinion upon the industrial development of the country, although the display was not by any means so complete as it might have been made.

The development of local industries no doubt accounts for the slow, though satisfactory, progress in the outside trade, compared with the rapid increase in the population and having regard to the extent of territory available for settlement. The extension of railways, and the fact that free trade prevails amongst the various provinces of the Dominion, has no doubt caused a large increase in the interprovincial trade, which does not appear in the trade and navigation returns. Take as an instance Nova Scotia coal. In 1865 , that is before the reciprocity treaty with the United States was abrogated, the total coal sold amounted to 635,586 tons, of which 465,194 were exported to the States, leaving 170,392 as consumed in the maritime provinces. In 1886 the total coal sales were $1,373,666$ tons, of which 60,646 tons only went to the United States, the balance being largely consumed in Nova Scotia, New Brunswick, Quebec, Prince Edward Island, and Newfoundland. Yet in the trade returns of 1886 Nova Scotia is only shown as exporting 233,000 tons. No doubt other instances could be given with regard to many commodities of which Canada imports less than formerly. But that the Canadians as a people are increasing in wealth and have more money at their command, will be apparent from the following table; and it is stated on good authority that the imports of Canada now include more articles of a valuable nature than formerly, the cheaper lines of goods at present made in the country superseding those of a similar kind previously purchased in Great Britain and in the United States :- 


\begin{tabular}{|c|c|c|}
\hline & 1868. & 1886. \\
\hline Deposits in the chartered banks of Canada & $\stackrel{\$}{\$ 2,808,104}$ & $\stackrel{\$}{\$}$ \\
\hline 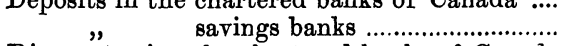 & $\begin{array}{r}3,4,360,692 \\
4,3\end{array}$ & $45,072,886$ \\
\hline Discounts given by chartered banks of Canada & $50,500,316$ & $165,044,608$ \\
\hline Imports & $73,459,644$ & $104,424,561$ \\
\hline Exports & $57,567,888$ & $85,251,314$ \\
\hline $\left.\begin{array}{l}\text { Shipping employed (not including } \\
\text { coasting ressels) }\end{array}\right\}$ tons & $12,982,825$ & $13,969,232$ \\
\hline Shipping employed (coasting trade) … , & $10,300,939^{*}$ & $16,368,274$ \\
\hline 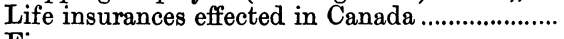 & $35,68 c, 082$ & $171,309,688$ \\
\hline $\begin{array}{l}\text { Fire } \\
\text { Business failures }\end{array}$ & $188,357,809$ & $611,794,479$ \\
\hline $\begin{array}{l}\text { Total consumption of coal (including ] } \\
\text {, production of coal tons }\end{array}$ & $\begin{array}{c}12,334,000 \top \\
714,893\end{array}$ & $3,515,769$ \\
\hline $\left.\begin{array}{c}\text { British Columbia, Nova Scotia, and } \\
\text { the North West Territory) .............. }\end{array}\right\}$ & 623,392 & $2,104,179$ \\
\hline 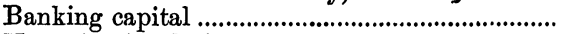 & $30,289,048$ & $61,841,395$ \\
\hline 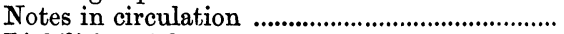 & $8,307,079$ & $29,200,627$ \\
\hline Liabilities of banks & $43,722,647$ & $147,547,682$ \\
\hline 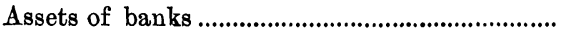 & $77,872,257$ & $228,422,353$ \\
\hline
\end{tabular}

* Figures only available since 1876 .

$+$

1874 .

The public revenue in the same time has advanced from $16 s .8 d$. to $28 s$. $6 d$. per head; and the net public debt from $\$ 75,728,64 \mathrm{I}$ to $\$ 223,174,107$. The net interest payable per head has however only increased from $5 s .4 d$. to $6 s .8 d$., which is owing to the improvement before referred to in the national credit. I am indebted for most of these figures to the returns appended to Sir Charles Tupper's budget speech last year, which is a mine of interesting and instructive information.

The exports of Canada are divided into six classes: the produce of the mine, the produce of the fisheries, the produce of the forests, animals and their products, agricultural products, and manufactures. A return of these since 1868 will be found in Appendix E. The principal countries to which goods are sent are Great Britain, the United States, Newfoundland, the West Indies, South America, and Australasia; but trade is rapidly growing with China and Japan, and France, Germany, and other European countries. It will be observed that in every class there is a fair increase; but the remarks made about the effect of the interprovincial trade apply as much to the exports as to the imports. I propose however, with your permission, to say a few words about each of the classes, as their development, and that of the industries connected with them, have such an important bearing on the future of Canada.

Minerals.-Canada is noted for the extent of its mineral deposits. The exports are chiefly coal, gold, copper, iron, phosphates, salt, antimony, mineral oils, and gypsum. Gold has been found in nearly every province, but is only worked to any extent in Nova 
Scotia, Quebec, and British Columbia. Silver mines of a very rich nature are in operation in Ontario and in the Rocky Mountains. Iron ore is found all over the Dominion, and many mines are in existence and projected. Some of the Canadian iron ores are among the richest in the world. Coal is found in Nova Scotia and British Columbia, and in the North West Territories. It will be seen from the figures that the exports of the mine have nearly trebled in the last twenty years. Until the recent extension of railways it was difficult to exploit the mineral wealth or to work it, especially in the region west of Lake Huron to the Pacific. The Geological Survey Department are engaged in exploring the various parts of the Dominion, and the reports that are issued by the Government periodically, indicate that minerals of almost every kind exist, and that their development will probably constitute one of the chief sources of the wealth of the country.

The Fisheries.-These are the largest in the world, embracing nearly 5,600 miles of sea coast, in addition to inland seas, innumerable lakes, and a great number of rivers. The importance of this industry will be recognised when it is stated that it employs nearly 56,000 fishermen and 29,240 vessels and boats. The display made by Canada at the Fisheries Exhibition in London in 1883 will no doubt be remembered. There is a Minister of Marine and Fisheries, a member of the Government, who has charge of all matters pertaining to these two important industries; and it may be said that close times and other restrictions to prevent unnecessary destruction of fish are in force in Canadian waters. The products of the fisheries exported and sold on the Dominion markets in 1886 amounted to $\$ 18,679,288$. This by no means represents the value of the total catch, for in Canada the home consumption is very great, $100 \mathrm{lbs}$. per inhabitant being calculated, as against $30 \mathrm{lbs}$. in England. As the fisheries extend throughout the length and breadth of the Dominion, almost every settler is afforded an opportunity for catching fish for domestic use. This renders it impossible to give full returns of the whole catch, but it is approximately estimated that the value of the home consumption last year was I 3 million $\$$, which with the exports makes up 3 I million $\$$ as the yield from less than half of the Canadian fisheries. The fresh water fisheries are also of great importance, the immense lakes and rivers supplying an abundance of fish of great commercial value, both for home consumption and export, besides providing sportsmen with some of the finest salmon and trout fishing to be found anywhere. The values of the yield of some of the principal fish in 1886 were cod, $\$ 4,553,079$; herring, $\$ 2$, 2 I 1,498 ; lobsters, $\$ 2,638,394$; salmon, $\$ 1,370,856$; mackerel, $\$ 1,556,424$; haddock, $\$ 747,685$; trout, $\$ 42$ I,400; sardines, $\$ 735,642$; white fish, $\$ 434,349$. Much attention has of late years been given to the development of the 
fisheries. The Dominion Government has granted a yearly sum of $\$ 150,000$ as a bounty, to be divided according to catch among the vessels and boats engaged in the prosecution of the sea fisheries. One result has been an increase in the number and a great improvement in the build and outfit of fishing vessels. There are also twelve fish breeding establishments in different parts of the Dominion, and millions of fry are yearly hatched and placed in the rivers and lakes. The large number of men and boys employed in the fisheries form a valuable addition to the naval strength of the empire; and the canning of lobster and salmon, and the drying of other fist, principally cod, for exportation, is also a large and growing industry.

The Forest.-The forest products of Canada constitute one of her most important sources of wealth. They find their way to all parts-to the United States, to the United Kingdom, South America, and to the Australian Colonies. The Canadian saw mills are at once among the most extensive and best appointed in the world. This industry in all its stages employs large numbers of men (about 10,000 in 1881), as well as affording freight to railways and shipping. Among the varieties of trees are the maple (hard and soft), elm, hickory ironwood, pine, spruce, cedar, hemlock, walnut, oak, butter-nut, basswood, poplar, chestnut, rowan, willow, black and white birch, and many more. Serious attention is now being given to replanting, with a view to preserve and replenish where necessary the great timber districts of the country. These forest trees add a singular beauty to the landscape, and also exercise a very beneficial influence on the climate in affording shelter and attracting rainfall. The beauty and brilliancy of the tints of the Canadian forest trees in autumn are remarkable.

Animals and their produce.-The exports include live animals, meat, butter, cheese, eggs, furs, hides and skins, and wool, and form the largest item in the classification of the exports. It is a trade which has been largely the growth of recent jears, and has been generally speaking a profitable one for farmers of the Dominion. In 1874 the total exports of cattle were 39,623 head, of which only 455 went to Great Britain. In 1886 the number had increased to 91,866, of which 60,549, valued at nearly a million $£$ sterling, were shipped to Great Britain. In addition the exports for the latter year included 16,535 horses and 359,000 sheep. There is fortunately no cattle disease in Canada, and animals coming from the Dominion are freely admitted into England, and are allowed to be moved about in the same manner as if they had been raised in the country. The cattle are of good quality, many pedigree and highly priced animals having been imported for the improvement of the flocks and herds during the last ten years. Herds of Shorthorns, Herefords, 
Galloways, polled Angus and Jerseys are to be found in many parts of Canada, which will bear comparison with those of any country. Great progress has been made in dairy farming, and the tendency is towards improvement and economy of labour. In connection with dairy farming the factory system is in operation in the older provinces. There are factories for the manufacture of cheese, and creameries for the manufacture of superior butter. "American" cheese as it is called is well known in England, but very few people are aware of the fact that the best "American" cheese is made in Canada. The export of Canadian cheese to the United Kingdom has largely increased within the last few years, indeed it is not long since that the Dominion was an importer. In 1868 the total exported was only $1,577,072$ lbs., and in 1886 it was $78,112,917$ lbs., valued at $\$ 6,754,626$. The export of butter amounted to nearly 5,000,000 lbs. in 1886 . Poultry to the value of $\$ 126,162$, and nearly $13,000,000$ dozens of eggs, were also shipped, largely to the United States.

Agricultural Products.-The exports under this head include general farm produce and fruit. There is a department of agriculture, with a member of the cabinet at its head, and legislative authority has recently been obtained for the establishment of five Government experimental farms in various parts of the Dominion, one at Ottawa, for Ontario and Quebec, one each for the maritime provinces, Manitoba, the North West Territories, and British Columbia, which are expected to prove valuable to the farming community, and I imagine the results of this new departure will be watched with much interest in Great Britain. Agriculture is still the leading industry of the country, and in 1881, according to the census returns, there were 680,000 persons so engaged. About 40 million dollars of farm produce, including animals and their products, and agricultural produce, were exported in 1886, in addition to that required for home consumption. For the quality of her cereals Canada occupies a place in the front rank, the Canadian exhibits of that class being the best at the Antwerp Exhibition, as testified by a committee of experts ; and at the Colonial and Indian Exhibition in 1886, the display of grains, fruits, \&c., made in the agricultural class by the Dominion attracted much attention. Mixed farming is generally carried on, the growing of grain and fruit, stock raising, and dairy farming being more or less combined. The general style of farming may not be so scientific as in Great Britain perhaps, but it is steadily improving, and the model and experimental farms will no doubt supply a stimulant in the same direction.

Manufactures.-I have already referred to manufactures in a previous part of this paper. It is only necessary to add that the principal general manufactures are not confined to any one part of 
Canada, they are to be found in all the older provinces on a larger or smaller scale.

But after all that can be said, it must be admitted that Canada, compared with many other and older countries, is, so far as the development of its resources is concerned, still in its infancy, although the progress made within the last twenty years when reduced to bare facts and figures will come as a surprise to a great many people. In the future, however, it will be surprising if the advance is not more rapid than anything yet witnessed, as recent events have tended to place Canada in a position she has not hitherto occupied, and of which every advantage is certain to be taken. Besides the fact that the resources and capabilities of Canada are yearly becoming better known, must attract the attention of persons having capital to invest. There is a large field open for capitalists, and the investment of money in developing the wealth of the country is sure to be beneficial to them and advantageous to the Dominion. In this connection I may say that the Dominion Government last year obtained authority from Parliament for the establishment of a department of trade and commerce, and results of a beneficial nature are expected to follow its inauguration. In bringing this portion of my paper to a close, I may mention that the total outside trade of the Dominion amounts to $\$ 39.57$ per head, divided into imports $\$ 2{ }^{\circ} 78$ per head, and exports $\$ 17 \cdot 79$. This compares very favourably with the United States, whose imports are equal to $\$ 10.84$ per head, and exports $\$ \$_{1} \cdot 59$, the total being $\$ 22{ }^{\circ} 43$, or in favour of Canada to the extent of $\$ 17^{\prime}$ I 4 per head.

It is impossible to speak of the future position of Canada without referring to the Canadian Pacific Railway. The idea of a transcontinental line from ocean to ocean has been mooted from time to time during the last fifty years, and I shall not attempt to say who originated it, but one of the gentlemen who interested themselves in the project, Major Carmichael Smith, in an open letter addressed to Mr. Haliburton, better known as "Sam Slick," published in 1847, made some remarks which are a monument to his farsightedness, and which condense in a few words almost everything that it is possible to say on the matter at the present day. The following is the quotation: "This great national highway from " the Atlantic to the Pacific is the great link which is required to " unite in one powerful chain the whole English race, which will " be the means of enabling vessels steaming from our magnificent " colonies, from New Zealand, Van Diemen's Land, New South "Wales, New Holland, from Borneo and the West Coast of China, " from the Sandwich Islands and a thousand other places, all "carrying the rich productions of the East, to land them at the " commencernent of the West, to be forwarded and distributed 
" throughout our North American provinces and delivered within " thirty days at the ports in Great Britain." It was only however in 1871 that the idea took form and shape on the occasion of the entry of the province of British Columbia into the Canadian confederation. One of the conditions was that the Dominion Government should secure the construction of a railway connecting that province with the railway system of Canada within ten years from the date of the union. The first survey party for the purpose of finding a practicable route commenced work in June, 1871, and from that date the surveys were continued every year. It was soon seen however that it would be impossible to finish the line according to the original terms, and a subsequent arrangement was made by which the time was extended to 1891. Comparatively slow progress was made in the work by successive Governments until 1881, when the present company was formed, which agreed to complete an all rail route across the continent to the Pacific coast within ten years. Their part of the work was to construct the line from Callender to Port Arthur and from the Red River to Savona's Ferry, British Columbia. The Government undertook to build the lines from Port Arthur to Winnipeg and from Savona's Ferry to Port Moody, which were, with the line from Emerson to Winnipeg, connecting Manitoba with the American system of railways, to be handed over to the company when finished. I need not however repeat the various terms of the contract relating to subsidies, \&c., as they are now so well known. The railway was to be completed and equipped according to the contract by the 1st May, 1891, but owing to the energy and enterprise of the company it was finished in December, 1885, nearly six years before the stipulated time, and it certainly occupies a place as one of the greatest engineering achievements of modern times. It is the shortest of the three great trans-continental highways, the distance from Montreal to Vancouver being 600 miles less than from New York to San Francisco, and the distance from Liverpool to China and Japan, viâ the Canadian Pacific Railway, is shortened by about 1,000 miles by the use of this route. The construction of this railway and of the Intercolonial Railway has cost Canada about 24 million $£$ sterling, equal to an annual burden of 1 million $\&$, and about 18 million acres of land. But the Canadians have not grumbled ai accepting this responsibility. As a result of these works, Canada has been consolidated and welded together, and I have no hesitation in saying that it is the most important event which has yet happened to British North America, and one whose influence upon the future of the country it is still premature to estimate. Each province has communication with the sea board, and in consequence a great impetus must be given to the trade and commerce of the Dominion. Eastern Canada has 
long had railway facilities, but Manitoba, the North West, and particularly British Columbia, have until recently remained more or less isolated, and therefore practically undeveloped. This however is now a thing of the past, the railway has opened up large tracts of fertile land in Manitoba and the North West, unencumbered with timber, ready for the plough, and considered to be the largest wheat field in the world, containing over 200 millions of acres all more or less suitable for agricultural purposes, for the growing of wheat and other crops, and for the raising of cattle. This part of Canada is therefore now in a position to offer, as well as the other provinces, bright and happy homes to a large number of people, and new markets for local and British products. Railway construction is not likely to stop with the completion of the Canadian Pacific Railway, branch lines are being rapidly made in Manitoba and the North West, and others are sure to follow. But it is rather with the future results of the line from imperial and commercial points of view that I propose briefly to deal; and in this connection I may say that its terminus has already been virtually extended from Vancouver to Hong Kong. The completion of the railway has in a measure altered the natural position of Canada, because it provides her with access to the Pacific Ocean, and consequently a position in the markets of China and Japan and Australasia, in the East generally, and in South America, which she has never previously enjoyed, and which promises a new era of commercial prosperity to the Dominion. The eastern provinces are rapidly becoming manufacturing centres, and it is believed that an immense field also exists for development in this direction in British Columbia, as it possesses coal and iron close to each other, abundant stores of timber, excellent water power, and plenty of good harbours, and is nearer to the Asiatic continent than any European country or the United States. Vessels are at the present time running at regular intervals between Vancouver and Hong Kong viâ Yokohama, but a new, regular, and fast service will probably be established in 1889, as Her Majesty's Government have recently announced their decision to provide, in conjunction with the Canadian Government, an annual subsidy to enable a line of steamers with an average speed of I 4 knots, constructed to meet Admiralty requirements, to be organised for the purpose. Without distinction of party this decision has been warmly welcomed throughout Great Britain. It is not unlikely also that before very long there will be a direct line of steamers established between British Columbia and Australasia. A portion of Her Majesty's mails for Australasia are now conveyed viâ New York and San Francisco, but as this contract will shortly expire, there is a very general feeling both in this country, in the Dominion, and in Australasia, that the opportunity should be taken of arranging for 
the conveyance of this postal matter entirely through British territory, and this would certainly require another line of fast steamers on the Pacific Ocean. This is the one link now wanted to place all the parts of the Empire in communication one with the other by means of steamers flying the Union Jack. The effect on Imperial interests in the Pacific Ocean, apart from the commercial results, of these lines of steamers, is sure to be of great importance.

There has also been much discussion lately as to the laying of a telegraph line across the Pacific, and the inauguration of closer commercial relations between Canada and Australasia which the steamship communication will bring about, will probably hasten the completion of this work. It was discussed at the Colonial Conference, and most of the delegates expressed themselves in favour of it. Indeed, there is such a general consensus of opinion in support of the proposal, that its completion must be simply a question of time.

There are many other imperial considerations connected with the Canadian Pacific route which deserve mention. It has generally been felt, and the opinion has received forcible expression during the last few months, that in time of war it would be impossible to rely upon the Suez Canal route as a regular means of communication with the East. The Cape route is no doubt a valuable one ; but the difficulties of coaling on the way would, it is said, serionsly impair its value not only for commercial purposes, but especially for the conveyance of troops and warlike material in time of war. None of these disadvantages can be said to apply to the Canadian Pacific route. The North Atlantic could certainly be pretty well patrolled and controlled by Great Britain, and the line from Halifax or Quebec is entirely through British territory. Then again there are abundant supplies of coal at Halifax and also at Vancouver; therefore with steamers crossing to China and Japan and to Australasia, with a speed hitherto unknown on the Pacific Ocean, we have a route as safe and secure as it is possible for any route to be, and upon which the speed can be guaranteed. Therefore the statement is justified, I think, that troops and munitions of war could be sent viô Canada to China and Japan, and Australasia, more safely and probably quicker than by any other way. Besides, if Halifax and Vancouver, in anticipation of any difficulty, were made into places d'armes, as in the case of Malta and Cyprus in recent years, bodies of troops could be conveyed from those places to India in a conparatively short time. It is to be hoped that such contingencies may never occur, but it is very necessary in these times to bear them in mind. There has been some discussion recently and some differences of opinion upon the distances viâ Canada to Australasia and the East, and I have therefore prepared a table (see Appendix F) which I trust may be of some value in this con- 
nection. The distances across the Atlantic and the Pacific Oceans, as well as by the other routes, have been placed at my disposal by the Admiralty; and the distance by the Canadian Pacific Railway has been added in order to enable a thorough comparison to be made.

I might refer, did space permit, to several other matters bearing upon the past and future of Canada, and among others the canals of Canada and the shipping interests, each of which deserves a special chapter. I can only mention them very briefly, bat I may say that it is now possible for large vessels to pass from the head of Lake Superior to Montreal through British waters-excepting at the Sault St. Marie lock connecting Lakes Superior and Huron-without change of cargo. The Dominion Government last year voted a million dollars towards the cost of constructing a new lock between the Lakes in question. The present lock belongs to the United States, who have always allowed Canada the use of it, but it is not large enough for the trade, and besides it is desirable that there should be a British lock connecting these two great inland seas. A very large traffic is carried on by means of the lakes in the summer season, in 1886 the tonnage of freight passing through the present canal at Sanlt St. Marie was $4,527,759$ tons. This is almost entirely the growth of the past few years, as five years ago the total traftic amounted to only 1,500,000 tons. Of course all this traffic does not go to Canada (the tonnage of freight carried over the Canadian canals in 1886 was nearly 2,600,000 tons), but it serves to show the importance of the great lakes and canals, and the use that is made of them. The money expended on the waterways of Canada amounts altogether to nearly 10 million $\&$ sterling. The shipping interests of Canada are also very important. The country owns a tonnage of $1,217,766$, and occupies the fifth position on the list of the world's shipping. Steamers to the extent of 257,818 tons are included in the above figures. The shipping trading to and from Canada in 1886 amounted to 2 I,37 I vessels, of $8,044,57$ I tons register.

In conclusion, I have only to say that the interest which is being taken in Canadian progress in Great Britain is observed with much gratification in the Dominion. Too much importance cannot be attached to the dissemination of information as to the position and resources of the colonies, and the various societies are doing so much good work in this direction, that it must be regarded as an evidence of their desire to bring about that closer union which is now so often discussed. The increase in population in Canada and the other colonies, and the consequent growth of commerce and mutual interests, must benefit both the colonies and the mother country, and add to the wealth, strength, and power of the whole Empire. 
A P PENDIX.

A.-Progress of Railway Construction in Canada.*

\begin{tabular}{|c|c|c|c|c|c|}
\hline Year & $\begin{array}{c}\text { Miles } \\
\text { in Operation. }\end{array}$ & Year. & $\begin{array}{c}\text { Miles } \\
\text { in Operation. }\end{array}$ & Year. & $\begin{array}{c}\text { Miles } \\
\text { in Operation. }\end{array}$ \\
\hline 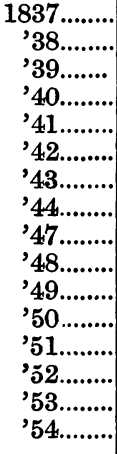 & $\begin{array}{r}16 \\
16 \\
16 \\
16 \\
16 \\
16 \\
16 \\
16 \\
59 \\
59 \\
59 \\
71 \\
93 \\
212 \\
423 \\
657\end{array}$ & 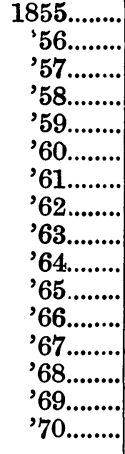 & $\begin{array}{r}855 \\
1,296 \\
1,428 \\
1,654 \\
1,997 \\
2,087 \\
2,087 \\
2,110 \\
2,110 \\
2,145 \\
2,145 \\
2,150 \\
2,258 \\
2,269 \\
2,497 \\
2,497\end{array}$ & 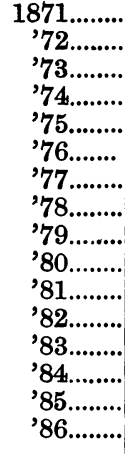 & $\begin{array}{r}2,497 \\
2,508 \\
2,638 \\
2,642 \\
4,826 \\
5,157 \\
5,5 \% 4 \\
6,143 \\
6,484 \\
6,891 \\
7,260 \\
7,530 \\
8,726 \\
9,658 \\
10,149 \\
10,697\end{array}$ \\
\hline
\end{tabular}

* "Railway Statistics of Canada," issued by the Minister of Railways and Canals, 1887.

B.-Railways in Canada in 1867.†

\begin{tabular}{|c|c|c|c|c|}
\hline Name. & $\begin{array}{c}\text { Miles } \\
\text { Con-- } \\
\text { structed. }\end{array}$ & $\begin{array}{c}\text { Expenditure } \\
\text { by } \\
\text { Government. }\end{array}$ & $\begin{array}{l}\text { Expenditure } \\
\text { from } \\
\text { Other Sources. }\end{array}$ & Total Cost. \\
\hline & & $\$$ & $\$$ & $\$$ \\
\hline Grand Trunk & 905 & I $5,142,633$ & $69,092,765$ & $84,235,398$ \\
\hline Montreal and Champlain ... & 83 & - & $2,417,680$ & $2,417,680$ \\
\hline Buffalo and Lake Huron ... & 160 & - & $8,000,780$ & $8,000,780$ \\
\hline 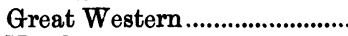 & 363 & $2,810,500$ & $21,966,930$ & $24,777,430$ \\
\hline Northern & 95 & $2,311,667$ & $3,146,122$ & $5,457,789$ \\
\hline London and Port Stanley ... & 24 & - & $1,032,850$ & $1,032,850$ \\
\hline Cobourg and Peterboro'......... & 32 & 一 & 900,000 & $9 c 0,000$ \\
\hline 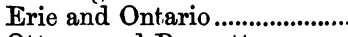 & 17 & - & 300,000 & 300,000 \\
\hline Ottawa and Prescott ............. & 54 & 一 & $2,008,994$ & $2,008,994$ \\
\hline Carillon and Grenville ........ & 13 & - & 98,761 & 98,761 \\
\hline St. Lawrence and Industry.. & 12 & - & 54,100 & 54,100 \\
\hline Port Hope and Beaverton ... & 56 & 一 & $1,993,580$ & $1,993,580$ \\
\hline Welland & 25 & - & $1,622,843$ & $1,622,843$ \\
\hline Brockville and Ottawa & 87 & $\ldots$ & $2,647,004$ & $2,647,007$ \\
\hline 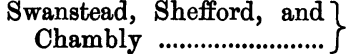 & 43 & $=$ & $1,216,000$ & $I, 2$ I 6,000 \\
\hline St. John and Shediac ............. & 148 & $4,073,385$ & 一 & $4,073,385$ \\
\hline St. Andrew's and Quebec ... & 99 & 110,000 & $2,000,000$ & 2, 110,000 \\
\hline St. Stephen's Branch ............ & 19 & 190,000 & 110,000 & 300,000 \\
\hline 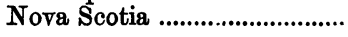 & 145 & $6,781,254$ & - & $6,781,254$ \\
\hline Total for all Canada ....... & 2,380 & $31,419,439$ & $118,608,417$ & $150,027,856$ \\
\hline
\end{tabular}

† "Statistical Abstract and Record of Canada," issued by the Minister of Agriculture, 1887. 
C.-Total Exports and Imports of Canada, 1868-86.*

\begin{tabular}{|c|c|c|c|}
\hline Year. & Total Exports. & Total Imports. & $\begin{array}{c}\text { Grand Total, } \\
\text { Imports and Exports. }\end{array}$ \\
\hline & $\$$ & $\$$ & $\$$ \\
\hline $\begin{array}{r}1868 \\
, 69\end{array}$ & $\begin{array}{l}57,567,888 \\
60,474,78 I\end{array}$ & $\begin{array}{l}73,459,644 \\
70,415,165\end{array}$ & $\begin{array}{r}131,027,532 \\
130,880,046\end{array}$ \\
\hline 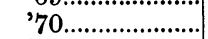 & $73,573,490$ & $74,814,339$ & $148,387,829$ \\
\hline '71.. & $74,173,618$ & $96,092,971$ & $170,266,589$ \\
\hline '72.... & $82,639,663$ & $111,430,527$ & $194,070,190$ \\
\hline '73... & $89,789,922$ & $128,011,281$ & $217,801,203$ \\
\hline '74_...................... & $89,351,928$ & $128,213,582$ & $217,565,510$ \\
\hline '75 ........................... & $77,886,979$ & $123,070,283$ & $200,957,262$ \\
\hline '76 ....................... & $80,966,435$ & $93,210,346$ & $\mathrm{I} 74, \mathrm{I} 76,78 \mathrm{I}$ \\
\hline '77....................... & $75,875,393$ & $99,327,962$ & $175,203,355$ \\
\hline '78......................... & $79,323,667$ & $49,081,787$ & $172,405,454$ \\
\hline $79 \ldots \ldots$ & $71,491,255$ & $81,964,427$ & I $53,455,682$ \\
\hline 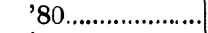 & $87,911,45^{8}$ & $86,489,747$ & $174,401,205$ \\
\hline ' $81 \ldots . . . . . . . . . . .$. & $98,290,823$ & $155,330,840$ & $203,621,663$ \\
\hline '82. & $102,137,203$ & $119,419,500$ & $221,556,703$ \\
\hline '83..... & $98,085,804$ & $132,254,022$ & $230,339,826$ \\
\hline 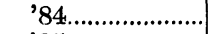 & $91,406,496$ & $116,397,043$ & $207,803,539$ \\
\hline 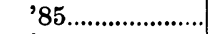 & $89,238,361$ & $108,941,486$ & $198,179,847$ \\
\hline 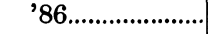 & $85,251,314$ & $104,424,561$ & $189,675,875$ \\
\hline Total ......... & $1,565,436,478$ & $1,946,349,513$ & $3,51 \mathrm{I}, 785,99 \mathrm{I}$ \\
\hline
\end{tabular}

* The percentage of duty on the total value of goods imported dutiable and free in 1868 was 12 per cent.; in 1878 it was 13.74 . In 1879 the national policy was inaugurated, and a general increase in the tariff was sanctioned by Parliament. The percentage in consequence increased in 1880 to 16.34 , and in 1886 it was 18.60 . Too much significance must not however be attached to these latter figures, as although some of the duties have been increased, many reductions have also been made, and many articles have been added to the free list. For instance, in 1880 the percentage of goods imported duty free was 20 per cent., while in 1886 it was 28 per cent. The amount of customs duties paid per head of population was $15 s .9 d$. and $18 s .5 d$. in the respective years.

D.-Principal Manufactures in Canada in 1881.†

\begin{tabular}{|c|c|c|c|c|c|}
\hline & $\begin{array}{l}\text { Invested } \\
\text { Capital. }\end{array}$ & $\begin{array}{l}\text { Yearly } \\
\text { Product. }\end{array}$ & & $\begin{array}{l}\text { Inrested } \\
\text { Capital. }\end{array}$ & $\begin{array}{l}\text { Yearly } \\
\text { Product. }\end{array}$ \\
\hline$\underset{\text { ments }}{\text { Agricultural imple- }}\}$ & $\begin{array}{c}\$ \\
3,995,782\end{array}$ & $\begin{array}{c}\$ \\
4,4 \circ 5,397\end{array}$ & $\begin{array}{l}\text { Musical instruments } \\
\text { Oil refineries }\end{array}$ & $\begin{array}{c}\$ \\
670,000 \\
1,812,700\end{array}$ & $\begin{array}{c}\$ \\
1,221,000 \\
4,050,000\end{array}$ \\
\hline Boots and shoes............ & $6,491,042$ & $17,895,903$ & Nail and tack factories.. & $1,245,500$ & $I, 689,450$ \\
\hline Cabinet and furniture & $3,943,419$ & $5,471,742$ & Paper factories............. & $2,237,950$ & $2,446,700$ \\
\hline Locomotive works ......... & $1,630,598$ & $3,956,36 \mathrm{I}$ & Preserving food .......... & $1,222,558$ & $2,685,861$ \\
\hline Cheese factories.............. & $1,021,435$ & $5,464,454$ & Rolling mills & 697,500 & $1,026,900$ \\
\hline ........................... & $3,476,500$ & $3,760,000$ & Saddle and harness.. & $1,323,845$ & $3,233,973$ \\
\hline $\begin{array}{l}\text { Distilleries } \\
\text { Engine building }\end{array}$ & $\begin{array}{r}1,303,010 \\
990,300\end{array}$ & $\begin{array}{l}\mathrm{I}, 790,800 \\
\mathrm{I}, 338,000\end{array}$ & $\left.\begin{array}{l}\text { Sash, door, and blind } \\
\text { factories }\end{array}\right\}$ & $1,996,858$ & $4,872,362$ \\
\hline $\begin{array}{c}\text { Fittings and foundry } \\
\text { work }\end{array}$ & $9,473,808$ & I $1,548,088$ & 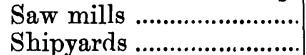 & $\begin{array}{r}25,487,233 \\
1,570,916\end{array}$ & $\begin{array}{r}38,541,752 \\
3,557,258\end{array}$ \\
\hline Elour mills...... & $13,857,923$ & 41,77 & Sugar refineries .... & $2,150,000$ & $9,627,000$ \\
\hline Furriers and hatters .... & $1,934,862$ & $3,352,961$ & Tanneries. & $6,386,222$ & $15,144,535$ \\
\hline Hosier & 630,821 & $1,385,730$ & Tin and sheet iron works & $1,993,054$ & $3,73^{8,246}$ \\
\hline Iron smelting furnaces & $2,172,100$ & $x, 197,5^{14}$ & Tobacco factories....... & $1,829,4,20$ & $3,060,300$ \\
\hline Meat curing & $1,450,000$ & $4,084,133$ & Wool cloth & $5,272,376$ & $8,113,055$ \\
\hline
\end{tabular}


E.-Exports of Canada, 1868-86.*

\begin{tabular}{|c|c|c|c|c|c|}
\hline Year. & $\begin{array}{c}\text { Produce } \\
\text { of the Mine. }\end{array}$ & $\begin{array}{l}\text { Produce of } \\
\text { the } \\
\text { Fisheries. }\end{array}$ & $\begin{array}{l}\text { Prodnce } \\
\text { of } \\
\text { the F'orest. }\end{array}$ & $\begin{array}{l}\text { Animals and } \\
\text { their } \\
\text { Products. }\end{array}$ & $\begin{array}{l}\text { Agricultural } \\
\text { Products. }\end{array}$ \\
\hline 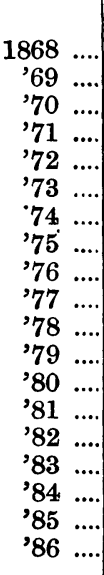 & $\begin{array}{c}\$ \\
1,446,857 \\
2,093,502 \\
2,487,038 \\
3,221,461 \\
5,326,218 \\
6,471,162 \\
3,977,216 \\
3,878,050 \\
3,731,827 \\
3,644,040 \\
2,816,347 \\
3,082,900 \\
2,877,351 \\
2,767,829 \\
3,013,573 \\
2,970,886 \\
3,247,092 \\
3,639,537 \\
3,951,147\end{array}$ & $\begin{array}{c}\$ \\
3,357,510 \\
3,242,710 \\
3,608,549 \\
3,994,275 \\
4,386,214 \\
4,779,277 \\
5,292,368 \\
5,380,527 \\
5,500,989 \\
5,874,360 \\
6,853,975 \\
6,928,871 \\
6,579,656 \\
6,867,715 \\
7,682,079 \\
8,809,118 \\
8,591,654 \\
7,960,001 \\
6,843,388\end{array}$ & $\begin{array}{c}\$ \\
18,262,170 \\
19,838,963 \\
20,940,434 \\
22,352,286 \\
23,899,759 \\
28,586,816 \\
26,817,715 \\
24,781,780 \\
20,128,064 \\
23,010,249 \\
19,511,575 \\
13,261,459 \\
16,854,507 \\
24,960,012 \\
23,991,055 \\
25,370,726 \\
25,811,157 \\
20,989,708 \\
21,034,611\end{array}$ & $\begin{array}{c}\$ \\
6,893,167 \\
8,769,407 \\
12,138,161 \\
12,608,506 \\
12,706,967 \\
14,243,017 \\
14,679,169 \\
12,700,507 \\
13,517,654 \\
14,220,617 \\
14,019,857 \\
14,100,604 \\
17,607,577 \\
21,360,219 \\
20,454,759 \\
20,284,343 \\
22,946,108 \\
25,337,104 \\
22,065,433\end{array}$ & $\begin{array}{c}\$ \\
12,871,055 \\
12,182,702 \\
13,676,619 \\
9,853,924 \\
13,378,891 \\
14,995,340 \\
19,590,142 \\
17,258,358 \\
211,139,665 \\
14,689,374 \\
18,008,754 \\
19,628,464 \\
22,294,328 \\
21,268,327 \\
31,035,712 \\
22,818,519 \\
12,397,843 \\
14,518,293 \\
17,652,779\end{array}$ \\
\hline Year. & Manufactures. & $\begin{array}{l}\text { Miscellaneous } \\
\text { Articles. }\end{array}$ & $\begin{array}{l}\text { Coin and Bullion } \\
\text { and } \\
\text { Estimated Amount } \\
\text { Short Returned } \\
\text { at Iuland Ports. }\end{array}$ & Foreign. & Total. \\
\hline 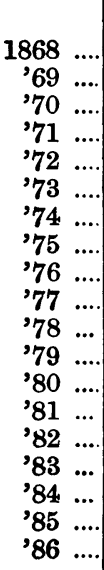 & $\begin{array}{c}\$ \\
1,572,546 \\
1,765,461 \\
2,133,659 \\
2,201,814 \\
2,397,731 \\
2,921,802 \\
2,353,663 \\
2,293,040 \\
5,353,367 \\
4,105,422 \\
4,127,755 \\
2,700,281 \\
3,242,617 \\
3,075,095 \\
3,329,598 \\
3,503,220 \\
3,577,536 \\
3,181,501 \\
2,824,137\end{array}$ & $\begin{array}{r}\$ \\
1,139,872 \\
1,430,559 \\
1,096,732 \\
949,090 \\
848,247 \\
1,248,192 \\
1,216,475 \\
1,198,631 \\
490,283 \\
320,816 \\
401,871 \\
386,999 \\
640,155 \\
622,182 \\
535,935 \\
528,895 \\
540,690 \\
557,374 \\
604,011\end{array}$ & $\begin{array}{c}\$ \\
7,827,890 \\
7,295,676 \\
10,964,676 \\
9,139,018 \\
6,897,454 \\
7,138,406 \\
4,811,084 \\
3,258,767 \\
3,869,625 \\
2,899,405 \\
2,418,655 \\
3,046,033 \\
4,575,261 \\
3,994,327 \\
4,466,039 \\
4,048,324 \\
4,885,311 \\
4,975,197 \\
2,837,729\end{array}$ & $\begin{array}{r}\$ \\
4,196,821 \\
3,855,801 \\
6,527,622 \\
9,853,244 \\
12,798,182 \\
9,405,919 \\
10,614,096 \\
7,137,319 \\
7,234,961 \\
7,111,108 \\
11,164,878 \\
8,355,644 \\
13,240,006 \\
13,375,117 \\
7,628,453 \\
9,751,773 \\
9,389,106 \\
8,079,646 \\
7,438,079\end{array}$ & $\begin{array}{c}\$ \\
57,567,888 \\
60,474,781 \\
73,573,490 \\
74,173,618 \\
82,639,663 \\
89,789,922 \\
89,351,928 \\
77,886,979 \\
80,966,435 \\
75,075,393 \\
79,323,667 \\
71,491,255 \\
87,911,458 \\
98,290,823 \\
102,137,203 \\
98,085,804 \\
91,406,496 \\
89,238,361 \\
85,2511314\end{array}$ \\
\hline
\end{tabular}

"Statistical Abstract and Record of Canada, 1887." 
F.-Distances to Australia and the East.

\begin{tabular}{|c|c|c|c|c|c|c|}
\hline & \multirow[b]{2}{*}{ From } & \multirow{2}{*}{$\begin{array}{c}\text { Viâ Suez. } \\
\text { Distance. }\end{array}$} & \multirow{2}{*}{$\begin{array}{l}\text { Viß Cape. } \\
\text { Distance. }\end{array}$} & \multicolumn{3}{|c|}{ VIâ Quebec and C.P.R. and Pacific. } \\
\hline & & & & $\begin{array}{c}\text { Total } \\
\text { Distance. }\end{array}$ & $\begin{array}{c}\text { Proportion } \\
\text { by Sea. }\end{array}$ & $\begin{array}{c}\text { Proportion } \\
\text { by } \\
\text { Railway. }\end{array}$ \\
\hline \multicolumn{2}{|c|}{ 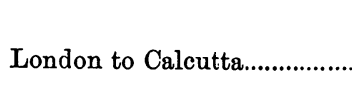 } & $\begin{array}{l}\text { Miles. } \\
7,95^{\circ}\end{array}$ & $\begin{array}{c}\text { Miles. } \\
11,780 *\end{array}$ & $\begin{array}{c}\text { Miles. } \\
14,726^{*}\end{array}$ & $\begin{array}{r}\text { Miles. } \\
11,671\end{array}$ & Miles. \\
\hline ", & 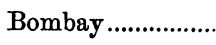 & 6,310 & $10,730 *$ & I $5,566^{*}$ & 12,511 & \\
\hline " & Fremantle, W.A. & 9,510 & 11,100 & 14,916 & 11,861 & \\
\hline$"$ & 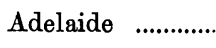 & 10,760 & 11,950 & I 3,606 & 10,551 & \\
\hline " & Melbourne.............. & 11,060 & 12,200 & 13,126 & 10,071 & \\
\hline ", & Sydney ...................... & I 1,530 & 12,750 & 12,576 & 9,521 &, 055 \\
\hline ”, & Brisbane ........ & 11,980 & 13,230 & 12,326 & 9,271 & \\
\hline " & Auckland ................. & $12,490 \dagger$ & $12,670+$ & 11,876 & 8,821 & \\
\hline$"$ & Hong Kong & 9,760 & 13,240 & I 1,656 & 8,601 & \\
\hline " & Yokohama... & 11,320 & 14,800 & 10,096 & 7,041 & j \\
\hline
\end{tabular}

* Distance from Vancouver to Calcutta, 9,, 10 miles.

$$
\text { " Bombay, } 9,85^{\circ} \quad,
$$

† Distance to Wellington, New Zealand.

Note.-Distance England to Quebec, 2,66r miles.

25 miles per hour on land equal to 600 miles per day.

\begin{tabular}{|c|c|c|c|c|}
\hline 12 knots & ", & at sea & " & 331 \\
\hline 14 & " & " & \# & 387 \\
\hline
\end{tabular}


G.-Railways in Canada,

\begin{tabular}{|c|c|c|c|}
\hline \multirow[b]{2}{*}{ Name of Railway. } & \multicolumn{2}{|c|}{ Length of Line. } & Tota \\
\hline & $\begin{array}{l}\text { Completed. } \\
\text { (Rails Laid). }\end{array}$ & $\begin{array}{l}\text { Under } \\
\text { Construc- } \\
\text { tion. }\end{array}$ & Subscribed. \\
\hline Bay of Quinté and Navigation Company & $\begin{array}{c}\text { Miles. } \\
\mathbf{5 1} \\
\mathbf{3}\end{array}$ & $\begin{array}{l}\text { Miles. } \\
\text { - }\end{array}$ & $\begin{array}{r}\$ \\
1,184,500 \\
105,000\end{array}$ \\
\hline Canada Atlantic, & 128 & - & $3,424,400$ \\
\hline$" \quad$ Southern ....................... & 362 & - & $34,493,936$ \\
\hline Canadian Pacífic & 4,319 & 207 & $183,606,793$ \\
\hline Montreal to Ottawa (Section Q. M.O. and O. Railway) & - & - & $5,802,956$ \\
\hline 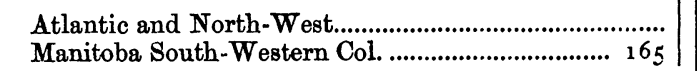 & 二 & $\underline{7}$ & $\begin{array}{l}180,000 \\
700,000\end{array}$ \\
\hline North Shore & - & - & $6,044,867$ \\
\hline St. Lawrence and Ottawa.......................................... $6{ }_{1}$ & - & - & $2,153,243$ \\
\hline Toronto, Grey, and Bruce & - & - & $5,678,938$ \\
\hline 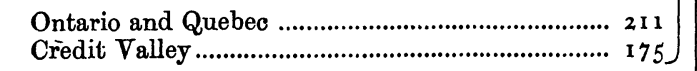 & - & 二 & $\begin{array}{r}11,590,000 \\
1,616,000\end{array}$ \\
\hline 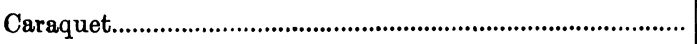 & 45 & - & $1,374,000$ \\
\hline $\begin{array}{l}\text { Carillon and Grenville } \\
\text { Central Ontario } \\
\text { Chatham Branch } \\
\text { Cobourg, Peterboro', and Marmora } \\
\text { Cumberland Railway and Coal Company }\end{array}$ & $\begin{array}{r}13 \\
104 \\
9 \\
35 \\
32\end{array}$ & $\begin{array}{l}\bar{z} \\
\overline{-}\end{array}$ & $\begin{array}{r}100,000 \\
3,170,000 \\
176,000 \\
1,158,240 \\
894,230\end{array}$ \\
\hline 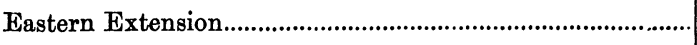 & 80 & - & $1,928,041$ \\
\hline Elgin, Petitcodiac, and Havelock & 27 & - & 584,150 \\
\hline $\begin{array}{l}\text { Erie and Huron Nanaimo } \\
\text { Esquimalt and } \\
\text { Graud Southern }\end{array}$ & $\begin{array}{l}72 \\
40 \\
83\end{array}$ & $\overline{30}$ & $\begin{array}{r}833,000 \\
2,531,717 \\
873,000\end{array}$ \\
\hline Grand Trunk & 2,598 & 二 & $233,436,969$ \\
\hline Buffalo and Lake Huron …............................... I 162 & - & - & $7,237,639$ \\
\hline Georgian Bay and Lake Erie ................................ I 72 & - & - & $3,258,250$ \\
\hline Montreal and Champlain Junction........................... 62 & - & - & $1,089,987$ \\
\hline Great Western ................................................. 540 & - & - & $18,280,660$ \\
\hline London and Port Stanley............................................. 24 & - & - & $1,121,861$ \\
\hline Welliugton, Grey, and Bruce .................................... 168 & - & - & $2,081,309$ \\
\hline London, Huron, and Bruce........................................... 69 & - & - & $1,4,24,986$ \\
\hline Brantford, Norfolk, and Port Burwell ................... 35 & - & - & 30,000 \\
\hline Midland & - & - & $12,874,880$ \\
\hline Toronto and Nipissing ........................................ 112 & - & - & $2,047,339$ \\
\hline Grand Junction & - & - & 445,500 \\
\hline Whitby, Port Perry, and Lindsay ………................ 47 & - & - & $31.7,053$ \\
\hline Victoria (Lindsay to Haliburton) …...................... 53 & - & - & 498,000 \\
\hline Madoc Junction to Bridgewater ............................... 9 & - & - & - \\
\hline Great Northern & 8 & - & 191,088 \\
\hline 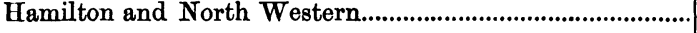 & 176 & - & $5,357,963$ \\
\hline
\end{tabular}

* "Railway Statistics," issued by the 
30th June, 1886.*

\begin{tabular}{|c|c|c|c|c|}
\hline Capital. & \multicolumn{2}{|l|}{ Government Aid. } & \multirow{2}{*}{$\begin{array}{c}\text { Municipal Aid. } \\
\text { Paid Up. }\end{array}$} & \multirow{2}{*}{$\begin{array}{c}\text { Total } \\
\text { Cost of Raulway } \\
\text { and } \\
\text { Rolling Stock. }\end{array}$} \\
\hline Pa:d Up. & Name of Government. & Paid Up. & & \\
\hline $\begin{array}{c}\$ \\
\mathrm{I}, \mathrm{1} 84,500 \\
80,000\end{array}$ & 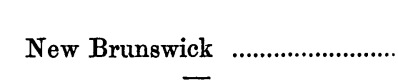 & 455,000 & $\begin{array}{l}\$ \\
70,000 \\
5,000\end{array}$ & $\begin{array}{l}\$ \\
1,783,356 \\
75,439\end{array}$ \\
\hline $\begin{array}{r}80,000 \\
3,318,480\end{array}$ & 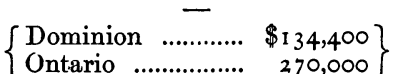 & $\overline{318,480}$ & $\begin{array}{l}5,000 \\
-\end{array}$ & $\begin{array}{l}75,439 \\
-\end{array}$ \\
\hline $34,493,936$ & , . . . . & 147,836 & 322,500 & $27,387,717$ \\
\hline I $73,146,705$ & $\begin{array}{l}\left\{\begin{array}{l}\text { Dominion } \\
\text { Ontario }\end{array}\right. \\
\text { Dominion }\end{array}$ & $\stackrel{57,243,519}{-}$ & 412,500 & $173,146,705$ \\
\hline $4,140,601$ & 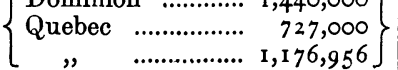 & $3,343,956$ & 796,645 & $7,500,000$ \\
\hline $\begin{array}{l}176,000 \\
700,000\end{array}$ & - & - & - & - \\
\hline $5,544,867$ & $\left\{\begin{array}{lrr}\text { Dominion } & \ldots . . . . . . . . . . & 954,000 \\
\text { Quebec } & \ldots . . . . . . . . . . . . . . .2,546,000\end{array}\right\}$ & $3,500,000$ & - & $5,599,651$ \\
\hline $2,153,243$ & - & - & 390,000 & $1,903,489$ \\
\hline $2,132,989$ & 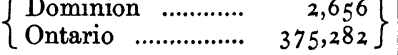 & 377,938 & 969,561 & $5,547,338$ \\
\hline $\begin{array}{r}11,590,000 \\
1,616,000\end{array}$ & Ontario & $\overline{531,000}$ & $1,08_{5,000}^{-}$ & $11,590,000$ \\
\hline 728,462 & $\left\{\begin{array}{ll}\text { Dominion ............ } & 224,000 \\
\text { New Brunswick.... } & 180,000\end{array}\right\}$ & - & - & - \\
\hline 100,000 & - & - & - & - \\
\hline $\begin{array}{l}970,000 \\
176,000\end{array}$ & $\begin{array}{l}\text { Ontario } \\
\text { New Brunswick }\end{array}$ & $\begin{array}{r}126,500 \\
32,000\end{array}$ & 93,500 & $\begin{array}{r}1,480,781 \\
176,000\end{array}$ \\
\hline $\begin{array}{r}1,158,240 \\
894,230\end{array}$ & 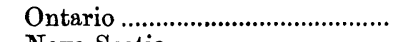 & 44,740 & II 3,500 & $\begin{array}{r}1,400,042 \\
702,331\end{array}$ \\
\hline $\begin{array}{r}894,230 \\
1,928,041\end{array}$ & 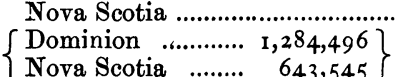 & $\begin{array}{r}144,230 \\
1,928,041\end{array}$ & - & $\begin{array}{r}702,331 \\
1,928,041\end{array}$ \\
\hline $5^{8} 4,150$ & $\left\{\begin{array}{rr}\text { Dominion ............. } & 38,400 \\
\text { New Brunswick .... } & 107,500\end{array}\right\}$ & 145,900 & 13,000 & 584,150 \\
\hline 828,500 & 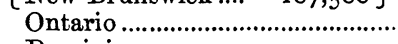 & 83,000 & 225,000 & 838,923 \\
\hline $1,809,217$ & 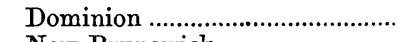 & - & - & $1,809,217$ \\
\hline 844,000 & 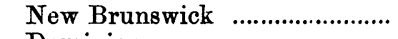 & 416,000 & 3,000 & - \\
\hline $233,406,899$ & Dominion & $15,142,633$ & 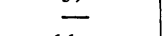 & $245,383,344$ \\
\hline $7,237,639$ & - & - & 966,000 & $6,271,639$ \\
\hline $\begin{array}{l}3,258,250 \\
1,089,987\end{array}$ & 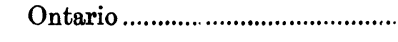 & 336,000 & 929,000 & \\
\hline $\begin{array}{r}1,089,987 \\
18,280,660\end{array}$ & 二 & $\overline{-}$ & - & $1,089,987$ \\
\hline $1,121,861$ & - & - & - & $1,121,861$ \\
\hline $2,081,309$ & 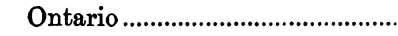 & 241,276 & 682,000 & $2,081,309$ \\
\hline $1,424,986$ & $"$ & 178,630 & 311,500 & $1,424,986$ \\
\hline 30,000 & - $\quad-$ & 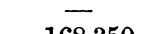 & - & - \\
\hline I $2,874,880$ & Ontario & 168,350 & 144,871 & - \\
\hline $2,035,54^{1}$ & $", \quad$ & 168,212 & 476,703 & 一 \\
\hline $\begin{array}{l}445,500 \\
317,053\end{array}$ & $", \quad$ & $\begin{array}{r}182,500 \\
94,958\end{array}$ & $\begin{array}{l}263,000 \\
222,095\end{array}$ & $16,017,973$ \\
\hline 498,000 & (1) & 312,000 & $\begin{array}{l}186,000 \\
182,090\end{array}$ & - \\
\hline 30,070 & - & - & - & - \\
\hline 191,088 & 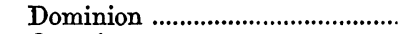 & 25,088 & 6,000 & - \\
\hline $5,255,363$ & Ontario & 565,020 & 775,596 & - \\
\hline
\end{tabular}

Minister of Railways and Canals, 1887. 
G.-Railways in Canada,

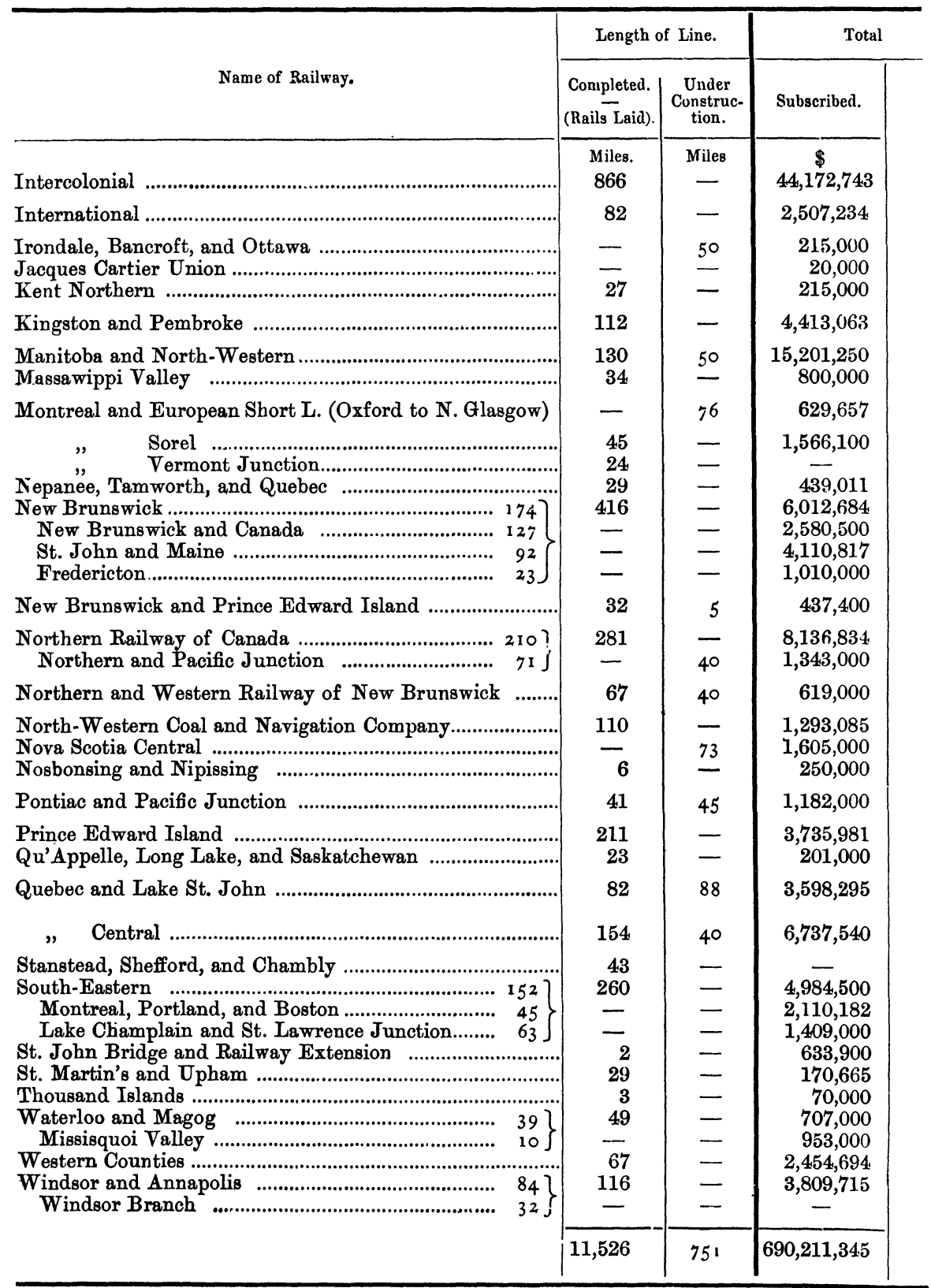


30th June, 1886-Contd.

\begin{tabular}{|c|c|c|c|c|}
\hline Capital. & \multicolumn{2}{|l|}{ Government Aid. } & \multirow{2}{*}{$\begin{array}{c}\text { Municipal Aid. } \\
\text { Paid Up. }\end{array}$} & \multirow{2}{*}{$\begin{array}{c}\text { Total } \\
\text { Cost of Railway } \\
\text { and } \\
\text { Rolling Stock. }\end{array}$} \\
\hline Paid Up. & Name of Government. & Paid Up. & & \\
\hline $\begin{array}{c}\$ \\
44,172,743\end{array}$ & Dominion & $\stackrel{\$}{\$ 4,172,743}$ & $\$$ & $\$ 44,172,743$ \\
\hline $2,494,434$ & $\left\{\begin{array}{lrr}\text { Dominion } & \ldots \ldots \ldots \ldots . . . & \text { 1 } 56,8 \mathrm{co} \\
\text { Quebec } & \ldots \ldots \ldots \ldots \ldots \ldots & 391,122\end{array}\right\}$ & 535,122 & 225,000 & $1,313,443$ \\
\hline $\begin{array}{r}5,500 \\
20,000\end{array}$ & 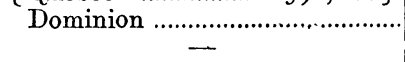 & - & - & - \\
\hline I 35,000 & 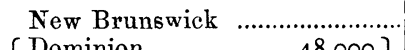 & 135,000 & - & 241,000 \\
\hline $4,413,063$ & $\left\{\begin{array}{lrr}\text { Dominion } & \ldots \ldots \ldots \ldots . . & 48,000 \\
\text { Ontario } & \ldots . . . \ldots \ldots \ldots \ldots . . . . . & 456,493\end{array}\right\}$ & 504,493 & 491,000 & $3,974,109$ \\
\hline $\begin{array}{r}6,45^{1}, 250 \\
800,000\end{array}$ & 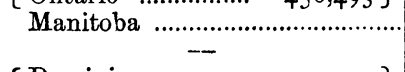 & ${ }^{386,250}$ & $\begin{array}{r}215,000 \\
65,000\end{array}$ & $\begin{array}{r}1,932,833 \\
800,000\end{array}$ \\
\hline 375,000 & $\left\{\begin{array}{lll}\text { Dominion } & \ldots \ldots \ldots \ldots . . . & 224,000 \\
\text { Annuit.y } & . . . . . . . . . . . . . . . & 155,657\end{array}\right\}$ & 125,000 & - & $\cdot=$ \\
\hline$\underline{1,544,972}$ & 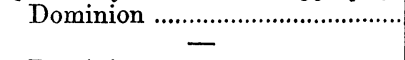 & $\underline{64,972}$ & - & $1,320,000$ \\
\hline 439, O I I & 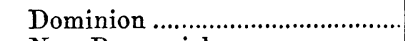 & 89,600 & 82,500 & 436,202 \\
\hline $6,012,684$ & New Brunswick ........................... & 76,000 & 23,000 & $3,677,480$ \\
\hline $2,580,500$ & (............................ & 575,000 & 47,500 & $3,546,000$ \\
\hline $4,110,8$ I 7 & (......................... & $1,180,000$ & 60,000 & $2,698,589$ \\
\hline 728,200 & ... & 230,000 & 80,000 & 728,200 \\
\hline 2 I I, OOO & $\left\{\begin{array}{lll}\text { Dominion } & . . . \ldots \ldots . . . & \text { I } 18,400 \\
\text { New Bruns wick .... } & \text { 1 } 88,000\end{array}\right\}$ & - & - & - \\
\hline $8,136,834$ & 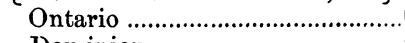 & 196,188 & 631,980 & - \\
\hline $1,229,030$ & 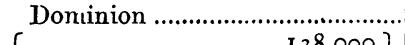 & $1,206,030$ & - & -- \\
\hline 401,000 & $\left\{\begin{array}{rr}\text { "............ } & 128,000 \\
\text { New Brunswick .... } & 321,000\end{array}\right\}$ & 251,000 & - & - \\
\hline $1,224,173$ & Than - & $\overline{11}$ & 一 & 676,953 \\
\hline $\begin{array}{l}124,476 \\
205,000\end{array}$ & 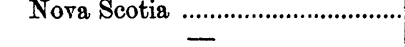 & 111,726 & - & - \\
\hline I 20,090 & $\left\{\begin{array}{lll}\text { Dominion } & \ldots \ldots \ldots \ldots . . & 272,000 \\
\text { Quebec..................... } & 510,000\end{array}\right\}$ & 90,090 & - & 585,646 \\
\hline $\begin{array}{r}3,735,981 \\
201,000\end{array}$ & 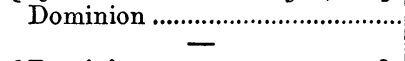 & $\underline{3,735,981}$ & - & $\begin{array}{r}3,735,981 \\
151,000\end{array}$ \\
\hline$I, 950,360$ & $\left\{\begin{array}{lrr}\text { Dominion } & \ldots \ldots \ldots \ldots . . . & 746,295 \\
\text { Quebec } & \ldots \ldots \ldots \ldots \ldots . . . & 1,445,000\end{array}\right\}$ & 791,518 & 210,842 & $2,334,160$ \\
\hline $6,586,682$ & $\left\{\begin{array}{lll}\text { Dominion } & \ldots \ldots \ldots \ldots . . & 21 \mathrm{I}, 200 \\
\text { Quebec } & \ldots . . . \ldots \ldots \ldots \ldots . . . & 681,250\end{array}\right\}$ & 741,592 & 103,000 & $6,526,340$ \\
\hline $4, \overline{856,392}$ & Quebec $\quad-$ & $\overline{315}, 892$ & $52 \overline{8,000}$ & - \\
\hline $2,110,182$ & , & 197,582 & 25,000 & - \\
\hline $1,264,280$ & 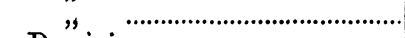 & 250,280 & 36,000 & - \\
\hline 10,827 & 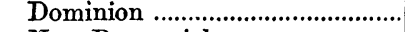 & - & - & 574,853 \\
\hline 160,665 & New Brunswick ........................... & 145,665 & - & 194,800 \\
\hline 70,000 & - & - & 10,000 & 72,412 \\
\hline 207,000 & Quebec & 92,000 & 15,000 & 一 \\
\hline 146,343 & , & 43,842 & $3^{8,500}$ & 一 \\
\hline $2,454,694$ & 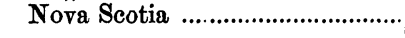 & 729,100 & 250,000 & - \\
\hline $3,8 \cap 9,715$ & $\quad, \quad[+\cdots \cdots \cdots$ & $1,089,674$ & - & $\mathrm{3}^{3,902,280}$ \\
\hline $653,376,145$ & & $144,305,147$ & $12,599,293$ & - \\
\hline
\end{tabular}


Discussion on Mr. J. G. Colmer's Paper.

Mr. W. Leigh Bernard thought that Mr Colmer deserved the best thanks of the Society for his very able and instructive paper on Canada, which had come at a very opportune time, when the affairs of that country were being taken up and discussed with a degree of interest unknown for some time past. Many persons were engaged in colonising different districts of Canada, he himself being associated with some gentlemen in colonising a portion of Alberta Province in the North-West Territory. The information to be derived from a study of Mr. Colmer's paper would be of great assistance to every one interested in the Dominion and its development. It was impossible for the public of this country to understand the merits of the different countries that were open for colonisation, unless the particulars of each country were placed before them by gentlemen like Mr. Colmer who could speak with authority on the subject. It was interesting to observe the small cost of construction of railways in Canada as compared with other countries; it seemed almost past belief that such a huge system of railways as there was in Canada could have ever been constructed for such small sums of money. When they cousidered that the capital sunk in the railways of Great Britain exceeded even the money invested in the national debt of the United Kingdom, it was very remarkable. that a young country like Canada, with only 5 millions of population, should have such a vast railway system, and he thought it presaged very great results for the future of that country. The fact that Canada was in the eighth position of countries with regard to railways was also very important to note, and the construction of the Canadian Pacific Railway six years before the time contemplated by the contract was a fact, he thought, unknown in the history of the construction of railways. One point in connection with Canada which had not been touched upon by the anthor of the paper, but which appeared to him very important, was the naturalisation laws. If any one emigrated to the United States, for example, they had to wait a considerable time before they could exercise all the rights of citizens, whereas in Canada they at once enjoyed all the privileges of citizenship as much as if they had lived there all their lives. He thought that was an important fact to be known by those wishing to settle in a new country, who do not wish to leave all the land-marks of their old country behind them. It had been pointed out how in the Colonial Exhibition they had seen so many of the products of Canada, and he was sure too much had not been said of the colonial products in that exhibition. It also seemed very remarkable that a country with a small population like Canada could actually be exporting food to the United States, a country with more than ten times the population, aud he was particularly struck 
with the figures with regard to the cheese productions; with regard to the shipping industry he was agreeably surprised to learn that Canada came fifth in the world as a maritime nation. He would have been very glad to have seen at the end of the paper some statistics comparing Canada with other countries, as regards railways in particular, and he hoped that the author would be able to add a tabular statement showing the comparison between Canada, the mother country, and other countries in that respect, though he was bound to admit that there was considerable difficulty in obtaining the information for such a table.

Sir George Baden-Powell, M.P., said he entirely re-echoed the remarks of the previous speaker. That the author had a complete and thorough knowledge of the subject was evident in every line of the paper. Mr. Colmer had shown them with regard to railway statistics what great advances Canada had made in giving to its national body politic the main arteries of communication. He had travelled over the continent of North America and over several other continents, and had carefully watched their railway communications, and he maintained that for the convenience of travelling, especially in winter time, there was no railway in the whole world that even approached the Canadian Pacific Railway. When travelling in various parts of the world he was in the habit of putting a thermometer on his pillow and taking a record at 11 o'clock every night. It was a.very severe winter when he was last travelling in Canada, and his thermometer always registered from $50^{\circ}$ to $55^{\circ}$ Fahr., which was a very pleasant temperature in which to go to bed. That was an indication of the way in which they made railway travelling comfortable in winter. It was one of the great causes of Canadian growth that the population could travel during the whole of the severest winter with such great comfort. In Parliament last, year a great effort was made to secure a subsidy for the trans-Pacific steamers of the Canadian route to the far East. The railway communications in Canada were of enormous importance to this empire, not only from a military but from the trade and postal points of view. Nobody expected or wished for war to break out, but if it did, there was now a sure, safe, and reliable means of communication, viâ Canada, with the far East, not only for mails but also for goods. Men-ofwar could not go long distances without coaling, and coal was a contraband of war. In order to intercept British commerce in the North Pacific, a war vessel leaving a European country would have to travel round South America, and there was no port where a man-of-war could coal. Wherefore at Vancouver both from Canada and England there was a base of operations which should keep the North Pacific clear of all hostile aggressors. That great advantage to English commerce would not have been within their grasp had it not been for the enterprise and loyalty of the Canadians in pushing through that great railway. $\mathrm{He}$ need hardly say how that railway was developing Canada, because the north-west districts, and especially British Columbia, would hardly be accessible to European trade were it not for the water 
and railway routes which had been opened up. The Australians too by means of that route hoped to connect their industries directly with Canada. There was a large trade in canned fish, both lobster and salmon, which was almost entirely of British Columbian origin, and it was hoped by many Australians that by the opening up of the Pacific ports, the Canadians would be able to carry on that trade direct instead of it coming through San Francisco or some other American port. He thought the Society was greatly indebted to the author for supplying so much information. Table F, in the paper, showing the distances to Australia and the East was of special interest, because it showed the actual facts on which they could base any policy, especially any financial policy, they might choose to start with regard to lines for steamers and telegraphic cables. The saving in mileage viâ Suez in the total distance from Great Britain to the various places was enormous. But it was often forgotten that whereas the average rate of the speed of ocean mail steamers was about 1.5 miles an hour, the speed already attained in the trip across Canada by railway was, he believed, something like 27 or 28 miles an hour, and when the through traffic was in active operation the speed would reach an average of 30 miles. In other words, for one-third of the distance viâ Canada the speed was twice that possible by other routes. He maintained that whichever route they took, they would have in time by the Canadian and Pacific route the shortest distance to go, and there would be an enormous saving in time to such places as Japan and China. A previous speaker had stated that he wished there had been added to the paper Australian and other colonial statistics. He (Sir G. Baden-Powell) confessed he saw a great difficulty in making out such comparative accounts, because the conditions existing in Australia, South Africa, and South America were so different, not only one fiom one another, but from those existing in Canada. If such comparative tables were compiled, it would be invaluable to have details with regard to the cost of the construction of railways. As far as he knew, Canada differed from the United States in the fact that her railways had not been so liable to the peculiar financial transaction which it was said was not unknown in America. The railways had been built fairly, cleanly, and honestly, and they knew very well where the money had gone, especially in regard to the recent railway undertakings. He thought a cordial vote of thanks should be passed to the author for having given such a valuable paper to the Society; a paper which described that great imperial undertaking which had been prophetically described so long ago as 1846 as "That great link which is required to unite into one powerful country the wholc English race."

Mr. F. Sharp Powell, M.P., said that if he was not out of order, he should be glad to second the vote of thanks to the author proposed by his name-sake. They must all have heen impressed a few months since in London by what was then seen of the actual results of Canadian industry, and of the bounty of nature in that great Dominion, and he thought it was extremely interesting that in so 
short a time after seeing that exhibition they should have such a valuable paper giving the full facts and concentrated essence of that which had so recently delighted the eye. What had struck him so much in connection with Canada was the mixture of courage, enterprise, and foresight, with controlling prudence. Some colonies had at times excited the misgivings of their best friends by the rapidity of their expenditure, and there might have been a doubt whether their resources were not being overtaxed; but he had never heard such a doubt expressed with regard to Canada. Great as had been the expenditure, there had been wisdom, and there was such an enormous amount of resources that safety prevailed, and there was no danger. He thought they might in some particulars adopt the policy of their Canadian fellow citizens, for instance with regard to timber. In some parts of the world timber was being cut down in such a reckless manner that there was a danger of the forests disappearing; but he observed that in Canada great care was taken to re-plant. They had been told that in Canada there was already a department of agriculture, with a member of the cabinet at its head. That had been promised in the House of Commons the previous evening for England and Wales, but even the details of the scheme had not yet been made public property. In England they were only just thinking that the Government might do something to teach agriculture, whereas in Canada that teaching was already carried out under the administration of the great Dominion. It must be a great relief to those who occupied the crowded cities of England to know that there were such a vast number of acres of land, which in years to come would bring ample supplies of food to the teeming populations. With regard to the railroads, he thought that an English railway proprietor might well envy the fate and fortune of his Canadian brother. In England owners of railways would in all probability undergo during the next few months a sharp experience, and their policy would be sharply challenged; but he found that in Canada the railways were supported by large subsidies of money, and by large grants of fertile land. So completely had the Government and the people gone hand in hand, that although the railways had cost 135 millions of money, upwards of 100 million $\&$ sterling had been spent out of private fortunes in order to build that gigantic system of railroads. It had been his fortune to be in Canada in 187l, and had had a conversation with Sir John Macdonald in the September of that year, at the time when the survey party spoken of in the paper had gone forth, and Sir John was speaking of what the result of that exploration might be. That great statesman said he had no doubt that the capital would be forthcoming, and his mind was in large measure at rest on that head. That railway as they knew, had now been made. It was difficult to realise its completion at so comparatively an early a period when its shadowing forth was so recent as 1871. On the River St. Lawrence there was a rapid called La Chine. A Frenchman a hundred years ago had said that that was the true road to China, and he called it La Chine rapid; that prophecy was repeated as a joke on the steamer as he descended the rapids in 1871, but that which was a 
jest in 1871, was an accomplished fact at the present time; because the railway passed within a very few miles of that rapid, and its course from east to west brought China a thousand miles nearer Liverpool than any other route. As the reader of the paper had stated, vessels were running regularly between Vancouver's Island and Hong Kong; and there was no doubt that the rapidity of their ocean navigation would bridge that ocean just as the great steamers have bridged the Atlantic Ocean between Liverpool and Quebec.' The sense which he entertained of the kind hospitality he had received in the Dominion, and his conviction that a great future was in store for her, made Canada the object of his affections, of his most sanguine hopes, and his largest expectations.

Mr. JAMES Mosse said that as chief engineer of part of the Inter-Colonial Railway in 1860, before it was taken up by the Federal Government, he should like to make a few remarks. In the first place he wished to mention a very interesting historical fact, which probably had not come under the notice of many persons. The first idea of the Inter-Colonial Railway between Halifax and Quebec was conceived in 1825 . In 1848 the Secretary of State for the Colonies sent out a party of officers of Royal Engineers, under the charge of Major Robinson, who made the preliminary survey. It was very rough, but it proved the possibility of making a railway, and it was considered an imperial more than a Canadian work. In order to avoid that terrible bend which the Ashburton Treaty allotted to the United States, instead of going through the State of Maine, it was taken round the coast of New Brunswick. That scheme for many years hung fire. In the meantime the Government of Nova Scotia made a certain portion of what was afterwards the Inter-Colonial Railway between Halifax and Truro. Of that particular portion he was afterwards chief engineer. The Government of New Brunswick then made another portion from St. John to Monckton and Shediac, which for several years ended there. Afterwards Brassey and Co. came in and made the Grand Trunk Line from Montreal to Quebec, and afterwards to River Du Loup, where it stopped, and it was not until the Dominion of Canada was established, about the year 1864, that the first survey was undertaken by the Canadian Government, under the charge of Mr. Sandford Fleming, C.M.G. Though the idea was first started in 1825 , it was not commenced until about 1866, and some ten years afterwards it was completed. In contrast to the Inter-Colonial Railway, which from first to last occupied some fifty years in cogitation and construction, the expedition practised on the Canadian Pacific Railway was most extraordinary. The works on 1,9 10 miles of main line were commenced in May, 1881, and completed in December, 1885. The modus operandi displayed a remarkable amount of organisation : the engineers went ahead "locating" the railway, then came the men employed on earthwork or "grading;" these were followed by the tracklayers, that is men laying the rails, and lastly came the waggons for housing the men and for carrying provisions. The whole work proceeded pari-passu, and with such expedition that 
the rails were laid at the rate of from $2 \frac{1}{2}$ to 4 miles per day during the working seasons. The cost of the Inter-Colonial Railway was $8,600 l$. per mile, which he thought was about the average cost of Canadian railways. The cost of course was very much less than that in England, though it was dearer than in the United States, because the railways were better built. The Inter-Colonial Railway was as substantial a railway as any in England, with the exception that it was a single line. Everything was built in the most solid and best manner. It was not however of much use to talk about the cost of railways, because what was cheap in one country was the reverse in another. Mr. Robert Stephenson speaking in 1856 at the Institution of Civil Engineers, stated that the cost of making the Trent Valley Railway very little exceeded the parliamentary expenses incurred in obtaining the Act, but of course in the colonies such expenses were not incurred. In new countries government land was granted free of cost, and all land was cheap, the accommodation bridges were few, and the railways could be made at a comparatively less sum. It depended upon the class of railway whether it was cheap or dear. Probably one of the most expensive colonial lines that was ever built was in Ceylon, where a railway was taken for 129 miles at an elevation of 5,280 feet above the sea, at a cost of 20,000l. to 24,000l. per mile. At the present moment the Government of Ceylon owned 122 miles of railway, for which they did not owe a single penny, whilst the railway from Colombo to Kandy had paid 8, 10, and i 2 per cent.

Mr. T. H. ELLiotT said that like most of the previous speakers he had been much impressed by the paper, which was an admirable summary of the commercial statistics of Canada. He had noticed with especial interest the remarkable extent to which Government interference appeared to be carried in Canada; in almost every direction Government aid was indicated. Mr. Colmer had referred to Government experimental farms, Government commissions of inquiry as to minerals, and especially to the very extensive Government assistance in railway matters. It would be very interesting to know to what extent they might attribute the Canadian success to this active co-operation and assistance on the part of the Government. It was to be remembered that in Canada in addition to the Government measures referred to, there was a highly protective system. If Canada had been fostered by that protective system, and if Government enterprise in different directions had really been the means of developing the country, the fact might possibly constitute a useful lesson in other directions. The report of the recent commission of inquiry as to the public works of Ireland had just been presented, and possibly a little of the same enterprise and practical Government assistance might result in the same development of that country as had been achieved in Canada. He should be glad to have some information from the author as to the relative position of Canada to the United States. At the present moment in England there was a notion that a movement was proceeding in favour of active commercial union with the United States, a movement which some feared might develop into 
proposals for political union with that country. He should be glad to learn Mr. Colmer's views as to the extent to which Canadian enterprise and prosperity had been affected by the relations of Canada with the United States, and especially whether those relations had in any way fettered Canadian progress. The facts contained in the paper seemed to him to supply answers to various points of inquiry, and enabled them to test the practice and actual working of economical theories. There had been great enterprise on the part of the Canadian Government, and he thought that similar enterprise in other directions might possibly lead to a similar happy result.

The Chairman (Mr. F. Hendriks) said that before calling upon the author of the paper to reply, he should like to ask a few questions with respect to railway statistics in which he did not find himself quite in accord with some of the previous speakers. $\mathrm{He}$ noticed that Mr. Colmer had said that the cost of 12,000 miles of Canadian railways had been about $8,500 l$. per mile. On looking at the figures however he thought they would find that the cost down to 1886 had been 12,216l. per mile. Of course statistically that was a very startling amount of difference; he thought however he saw how it was accounted for : in his estimate of the lower average of 8,500l. per mile the author had omitted to include Government and municipal aid. He submitted that that was not quite right from a statistical point of view. If the Government and the municipalities of Canada had come forward, as shown by the statistics, with $\$$ I $56,904,000$ in aid of the railways, this had entailed so much debt and burden upon the Dominion of Canada, and consequently the outlay upon railways must be reckoned inclusive and not as exclusive of this large investment in aid of a special enterprise. The investment, it might be said, was to some extent recuperatire, for it had the chance of producing in the end some interest or dividend. But this did not differ at all from the position of the expenditure of other and private shareholders, and he could not distinguish the one from the other. It had been suggested by one or two speakers that it would be useful to make comparisons with other countries. Of course in those matters they must be careful not to pat together in parallels things comparatis non comparandis, the circumstances being so very different; at the same time he thought the author had a little challenged such a proceeding where he spoke of the capital expenditure of our London and North Western Railway, with its 1,800 miles of line having been as great as the cost of 12,000 miles in Canada. But such a comparison must be qualified by looking into facts. It was quite true that the railways in the United Kingdom had cost $43,365 l$. on an average per mile, calculated to the year 1886, as contrasted with $12,216 l$. per mile in Canada. But look at the enormous difference in the traffic and the earnings in the two countries respectively, and observe that the earnings of the railways of the United Kingdom in 1886 were in proportion to those of Canada as five to one, in other words they were nearly five times as productive in gross revenne. He would not make a comparison as to the effect upon the revenue returns 
arising from the number of passengers carried, although in the United Kingdom it was eighty times as great as in Canada, seeing that the British railways included so many short lines, where the frequency of short journeys told upon the comparative number of travellers. There was another point which required explanation, namely, why the working expenses continued to be so enormous in Canada. In England they were only 52 per cent., while in Canada they remained at $72 \frac{1}{2}$ per cent. He must confess that he did not take quite the same view as the author with reference to the history of railways in Canada, for the early chapters in that history, and particularly as regards the "Grand Trunk Railway," were certainly very distressing to the people of this country. Nor did he agree with what Mr. Elliott had said with regard to the help which Canada had received from its Government, for the real helpers of Canada at the outset of her railway enterprise were the citizens of London. And in this matter of early railway construction the capital for it would never have been forthcoming but for the faith which was too implicitly reposed at the time in some ill-consiructed statistical data as to the net return to be expected from Canadian railways, and which were put forward for the information of London shareholders under the authority of Canadian representatives, and with the names on the prospectuses of eminent London financiers more or less connected with the Government agency and other interests of Canada. He did not make any imputation upon those gentlemen, for they no doubt believed at the time when the Grand Trunk Railway was started that those statistics were accurate, but they were far too sanguine in anticipating a greater increase in the value of land and extent of railway-using population than had yet taken place. If its own Government help instead of that of the public of the city of London had been waited for, the progress of Canada would never have been so great. At the same time there was some "balm in Gilead," for the trade of Canada was rapidly developed through the early construction of the Grand Trunk Railroad, and there had been sume indirect return no doubt to the London commercial public from the profits of trade between the two countries. At the same time he thought it was a most flagrant illustration of the error of supposing that it ever would be good policy for colonials to be waiting upon Government to help them forward in enterprises which could best be conducted by private energy and capital. Colonials who did not help themselves, but waited for Government initiative would be nowhere in the modern race of competition. In all other results the progress of the Dominion as exemplified in the paper was most gratifying. It was one good proof of Canadian prudence that they were not overcharged with debt; because, according to the figures given by the author, the present interest per head amounted to no more than $6 s .8 d$, whereas in the United Kingdom it was nearly $16 s$. Therefore, considering that the population of Canada was, on the average, a very well-conditioned one, the burden of $6 s .8 d$. per head was very slight. Now that the "Central Pacific Railway" was formed, and more money was wanted for it, the Canadian Government could very well afford to take their chance in that enterprise, although they were but feeble 
helpers indeed when the Grand Trank Railway was being first instituted. It was gratifying too, as the sign of a well-to-do community, to see the large amount of deposits, amounting to nearly 150 million dollars, in the hands of Canadian chartered banks and savings banks. That amount however was not so large in proportion to the population of Canada as in the case of the English banks. The population of Canada might be taken as five millions-about one-seventh of the population of the United Kingdom-bnt the deposits in the Canadian chartered banks were not more than one twenty-seventh part of those in the United Kingdom. At the same time a fact of some importance in making such a comparison ought to be kept in view, and that was, and particularly in old countries, that a large proportion of those deposits represented idle capital. The imports and exports of Cauada were very considerable for a comparatively modern community. They did not however amount in proportion to those of England to more than one-seventeenth in value for imports, and one-thirteenth for exports. With regard to life assurance, it was gratifying to see such an amount of thrift in a comparatively new colony, for the anount was about one-fifteenth of that effected in this country. He was sure the meeting would accord a hearty vote of thanks to the author for his most valuable contribution to the Journal.

Mr. Stephen Bourne said he should be loth as an old member of the Society, and having experienced Canadian hospitality, to remain silent in not thanking the reader of the paper for the information he had put before them, and likewise in not expressing the greatest desire for the prosperity of the Canadian empire. The subject of imports and exports was rather a sore point between Mr. Colmer and himself, and they had had many passages of arms with regard to the tariff system. The small quantity of imports and exports arose from the fact that Canada instead of consuming the manufactured produce of England, as all the other colonies did to a great extent, and sending us food and raw material, exercised her capability of producing manufactured goods for herself, and therefore the intercolonial trade was larger in proportion than the foreign trade. How far the prosperity of Canada might be due to the protective system he could not say. He thought that Canada would have advanced with much more rapid strides had she not fallen into that error, and when once she awoke to the perception of the importance of free trade, especially with the mother country, she would advance with still greater rapidity. He had been asked before he came to the meeting how it came about that Canada could be so prosperous under the protective sy:stem. The explanation of that was twofold. In the first place she was constantly receiving from England a large amonnt of living machines, instruments for work born and raised and trained at the expense of the mother country, therefore she ought to be prosperous beyond the country which sustained the drain of producing that machinery. Again, the construction of her railways and the development of her internal resources had been, as the Chairman properly remarked, fostered in the city of London, from whence there had been sent a large amount of capital to be 
expended in that country, which necessarily had been productive of great prosperity for the time. The same thing had happened in New Zealand, which country was now in a considerable state of depression, almost in danger of bankruptcy, because she had obtained labour and capital beyond her means of profitably employing. They had been told that the amount of money on deposit in savings banks and life assurance offices was small, but he was not disposed to look upon that as an unfavourable symptom. He did not think they could measure the prosperity of a country by the amount of idle capital invested in savings banks and life assurance offices. He for one was not disposed to look with very great favour upon large investments in life assurance. In the long run it stood to reason that the expenditure of the individuals who insured their lives must be more than the sums they received in the end, because there was a vast amount of labour employed in the transaction and profit to those who carried it on. With regard to the railway system of Canada, of course no comparison could possibly be of any value between the cost of railways in different countries. The beauty of her railway system was that it connected the distant portions of the empire. $\dot{H}$ e could not quite coincide with the encomiums passed upon the security with which Canadian railways were built: in a fifteen days' journey up to the Rocky Mountains, two days were occupied in being detained by accidents happening from insufficient construction. He did not blame the Canadians at all for that, because the railways were necessarily hastily and cheaply constructed for immediate purposes, but as they were used and became of more value, they would be strengthened and increased, and then the expense of their construction would appear very much greater than it had been hitherto. Still it was a grand enterprise, and a wonderful proof of industry, courage, daring, and foresight, which had thus bridged the continent from one ocean to the other.

Mr. J. G. Colmer, in reply, begged to thank the Chairman for the kind and flattering way in which he had referred to his paper, and the meeting for the generous reception they had accorded to it. He was also particularly grateful to those gentlemen who had taken part in the discussion for the valuable information with which they had supplemented his paper. Mr. Elliott had spoken upon the subject of the relations between Canada and the United States. With regard to that he could say that Canada was one of the most loyal portions of the British Empire. Canadians venerated the British connection, and he did not think they would do anything to bring about a separation. In a very strong opposition paper in Canada the other day, he read a remark to the effect that. if a man wanted to address a meeting upon the subject of annexa. tion to the United States, he would probably have to address empty houses ; and Sir Charles Tupper had also said he was sure no man would have the least chance of being elected to the Dominion House of Commons who adrocated such a policy. Here therefore was the feeling of both political parties on the matter. Canada's commercial relations with the United States had always been most 
friendly. They had always done their utmost to promote and foster those feelings, and he believed some good results in this direction would probably be the outcome sooner or later of the negociations which had recently been going on. Besides, in the interesting message which the President of the United States recently presented to the Congress, a disposition was shown to relax the high duties upon trade generally, and he thought that would be advantageous to the Dominion. With regard to the cost of railways, of course he did not mean in any way to make comparisons. He was only dealing with the subject from a public investment point of view; he merely said that railways in Canada cost 8,500l. of public money. He thought it necessary to mention that, because it was only upon that portion of money that dividends had to be paid. The Government contributions had as a rule been given absolutely, and no return was expected except in the development which must take place in the country owing to the construction of the railways. As a matter of fact he pointed out that, speaking generally, investors had only paid $8,500 l$. per mile for their railways, although they had really cost about $12,000 l$. In the case of working expenses it was difficult to make any comparison between the working expenses of colonial railways and the working expenses of British railway.s. Labour had to be paid at a mach higher rate in the colonies than the mother country; the railways were made much more cheaply than in England, consequently a larger amount was required to be spent in maintenance, and it was also necessary to bear in mind that probably the current rate of expenses would enable a much larger traffic to be carried than was done at the present time. He mentioned in one part of his paper that the working expenses in 1877 were 81 per cent., and in 1886 they had fallen down to 72 per cent., showing that although the traffic had developed in a very marked degree during that period, the expenses instead of increasing had decreased very rapidly. With regard to the remarks of Mr. Stephen Bourne upon the tariff, he might mention that in Canada there was a practical unanimity of opinion with regard to the fiscal policy. At the recent general election both parties were united in regard to it, and both supported it. Mr. Stephen Bourne would admit that the country had made very rapid progress, notwithstanding the disadvantages under which he considered it had laboured, and that its condition was not unsatisfactory. It must be remembered that a policy which might be good for one country might not be good for another, and that local circumstances require consideration in every case of the kind. They might be certain that the interest of Canadians was not in any way to restrict trade, but rather to increase it with the mother country and other nations, and they were not likely to take any steps that would in any way diminish their present trade returns. They were very glad to get all the emigrants they could of the right classes, for they not only benefited the colonies, but also the mother country, where there were at present too many people. There could be no doubt that the development of the colonies within the past twenty years liad had a wonderful effect on British trade returns, and this was largely owing to the construction of railways and to increased immigration. 